\title{
Seascape genomics reveals population structure and local adaptation in a widespread coral reef snail, Coralliophila violacea (Kiener, 1836)
}

Sara E. Simmonds ${ }^{1 *}$, Samantha H. Cheng ${ }^{1,2}$, Allison L. Fritts-Penniman ${ }^{1}$, Gusti Ngurah Mahardika $^{3}$, Paul H. Barber ${ }^{1}$

${ }^{1}$ Department of Ecology and Evolutionary Biology, University of California Los Angeles, 612 Charles E. Young Dr. East, Los Angeles, CA 90095, USA;

${ }^{2}$ Center for Biodiversity and Conservation, American Museum of Natural History, 200 Central Park West, New York, NY 10024, USA;

${ }^{3}$ Animal Biomedical and Molecular Biology Laboratory, Faculty of Veterinary Medicine, Udayana University Bali, J1. Raya Sesetan, Gg. Markisa 6, Denpasar, Bali 80223, Indonesia;

*Corresponding author's current address: sara.koch@gmail.com, Department of Biological Sciences, Boise State University, Boise, ID 83725-1515

Seascape genomics (high-throughput genomics coupled with ocean climate databases)

facilitates the exploration of neutral and adaptive variation in concert, developing a

used a seascape genomics approach to test the relative roles of neutral and adaptive processes shaping population divergence of a widespread coral reef snail, Coralliophila violacea. We collected C. violacea from colonies of their coral host (Porites spp.) at ten

27 locations spanning a large portion of their geographic range. We used RAD-seq to investigate possible local adaptation via genetic-environmental associations with five ocean climate variables. Four genetic partitions were concordant with regions previously observed in mtDNA (Indian Ocean, Coral Triangle, and Hawaiian Islands), with the

31 addition of Vietnam and varying isolation and admixture levels. We identified outlier loci 
33 34), suggesting that some loci are putatively under divergent selection. Association analyses showed that the two strongest drivers of local adaptation were the annual range

35 and mean of sea surface temperature. Populations that experience lower sea surface

36 temperatures at the periphery of $C$. violacea's geographic range drive these associations.

37 Our results show that local adaptation to different environments likely reinforces neutral 38 divergence, especially in peripheral populations.

Keywords: Coral reef, Coralliophila violacea, local adaptation, peripheral populations, seascape genomics, RAD-seq

\section{INTRODUCTION}

44 Incomplete or ephemeral dispersal barriers, combined with potentially large population sizes and 45 extensive geographic ranges of marine taxa, suggest that natural selection plays a crucial role in generating biodiversity in the ocean (Crandall et al., 2012). Authors are increasingly advocating

47 for speciation models that combine both neutral and adaptive processes (Bowen et al., 2013;

48 Horne, 2014) because natural selection limits realized connectivity between populations

49 (Burgess et al., 2012). Local adaptation to climate and habitat can reinforce neutral divergence

50 patterns driven by gene flow, genetic drift, or mutations (Gavrilets, 2003). In these models, even

51 species with high fecundity and long dispersal distances can have low effective gene flow if

52 selection favors local progeny over those recruiting from different environments.

54 diversification of marine taxa than previously thought. For example, several studies show

55 environmental and habitat heterogeneity (Longo \& Bernardi, 2015; Rocha \& Bowen, 2008; 
56 Teske et al., 2019), or competition among species (Bowen et al., 2013; Briggs, 1992), drive

57 diversification or reinforce nascent allopatric divergence. Similarly, recent work also suggests

58 that divergent selection between habitats or hosts contributes to adaptive variation and speciation

59 (Cheng, 2015; Meyer et al., 2005; Reid et al., 2006; Simmonds et al., 2020; Tornabene et al.,

60 2015).

61 Natural selection can be particularly influential in peripheral areas of species' ranges where

62 environmental conditions may be at or near the limits of a species' physiological threshold (J. D.

63 DiBattista et al., 2016; Gaither et al., 2010; Johannesson \& André, 2006; Kawecki, 2008),

64 creating different selective pressures.

65 Studies using high-throughput genomic tools have found signals of natural selection

66 driving genetic divergence in peripheral marine populations (Ackiss et al., 2018; Gaither et al.,

67 2015; Saenz-Agudelo et al., 2015). Authors hypothesized various mechanisms driving

68 divergence, including different ecological (e.g., habitats) and environmental factors (e.g., sea

69 surface temperature, salinity, turbidity), but also seasonal fluctuations or environmental

70 heterogeneity (e.g., oceanography) at smaller scales that indicate selective processes at play. As

71 such genomic sequencing, combined with global, high-resolution marine environmental

72 databases (Sbrocco \& Barber, 2013), meaning we can now directly assess the role of natural

73 selection driving or reinforcing diversification in the ocean.

74 In recent decades, geneticists have documented phylogeographic structure in a wide diversity of

75 marine taxa (Bowen et al., 2014; Kelly \& Palumbi, 2010), advancing allopatry as a primary

76 speciation model in marine ecosystems, particularly among studies of Indo-Pacific biodiversity

77 (Barber et al., 2011; Bowen et al., 2013; Carpenter et al., 2010; Gaither et al., 2010). Authors

78 often report one or more of the following phylogeographic patterns: 1) population divergence 
between Indian and Pacific Ocean basins; 2) population differentiation within the Coral Triangle, the global epicenter of marine biodiversity; or 3) population differentiation on the periphery of

81 the Pacific (e.g., Hawai'i, Marquesas) or Indian Oceans (e.g., Red Sea).

The divergence between the Indian and Pacific Oceans is typically ascribed to the Sunda and Sahul continental shelves' exposure when Plio-Pleistocene glaciations lowered sea levels by 115-130m (Voris, 2000). These intermittent landmass barriers constricted waterways of the Indonesian and Philippine Archipelago, reducing gene flow between the Indian and Pacific Oceans in a wide diversity of marine taxa, including seahorses (Lourie et al., 2005); soldierfish (Craig et al., 2007); anemonefish (Dohna et al., 2015; Timm \& Kochzius, 2008); damselfish (Drew \& Barber, 2009; Liu et al., 2014; Raynal et al., 2014; Liu et al. 2019); groupers (Gaither et al., 2011); fusiliers (Ackiss et al., 2013); limpets (Kirkendale \& Meyer, 2004); snails (Crandall et al., 2008a; Reid et al., 2006; Simmonds et al., 2018); giant clams (DeBoer et al., 2014; Nuryanto

$91 \&$ Kochzius, 2009) and seastars (Kochzius et al., 2009). Further studies suggest that modern oceanographic features such as the Halmahera Eddy can limit gene flow within the Coral

93 Triangle by constraining larval exchange, a hypothesis supported by both phylogeographic

94 studies (Ackiss et al., 2013; Barber et al., 2011; DeBoer et al., 2008) and biophysical

95 connectivity models (Kool et al., 2011; Treml et al., 2015).

Although multiple processes contribute to isolation and divergence in the sea (Barber \&

97 Meyer 2014), purely allopatric models of marine speciation still face challenges. For example,

98 while Plio-Pleistocene sea levels did constrict Indonesian and Philippine waterways (Voris,

99 2000), the major pathways for the Indonesian Throughflow, the Makassar Strait, Maluku, and

100 Banda Seas, are deeper than 3,000 m. Thus, even at the lowest sea levels, these dispersal

101 pathways between Pacific and Indian Oceans remained open, requiring authors to invoke 
102 auxiliary processes such as increased upwelling of cold water as a mechanism to limit dispersal

103 (Fleminger, 1986). Moreover, periods of isolation were punctuated by tens of thousands of years

104 of oceanic conditions similar to today's, during which gene flow and population expansion

105 would have occurred, weakening the signal of historical isolation (Crandall et al., 2008b).

106 Similarly, ocean currents in the region vary, both seasonally (Shinoda et al., 2012) and across

107 epochs (Kuhnt et al., 2004), such that oceanographic features may promote isolation during some 108 periods only to be reversed in others.

109 The coral-eating snail Coralliophila violacea (Kiener, 1836) is widespread on coral reefs

110 across the tropical Indo-Pacific, from the Red Sea to the Eastern Pacific (Demond, 1957), and

111 may be subject to both neutral and selective processes for divergence. Previous work on $C$.

112 violacea demonstrated genetic differentiation of snails living on different coral host lineages,

113 despite ongoing gene flow (Simmonds et al., 2020; Simmonds et al., 2018). One lineage was

114 broadly distributed but exhibited phylogeographic structure in the core of its geographic range

115 (i.e., across the Sunda Shelf) and peripheral populations (i.e., Hawai'i). This structure could be

116 attributed to allopatric processes, such as isolation during low sea-level stands or isolation by

117 distance. However, given that environmental conditions vary greatly, it is possible that variation

118 in ocean climate across the range of $C$. violacea could reinforce population divergence via

119 natural selection.

120 This study combined genome-wide surveys of genetic variation in C. violacea

121 with data from marine environmental databases to test the relative roles of neutral and

122 adaptive processes shaping population divergence. Specifically, we test for divergence

123 across known phylogeographic provinces within the Coral Triangle and divergence

124 among peripheral populations in the Indian and Pacific Oceans and the South China Sea. 
125 We then compare neutral and non-neutral variation patterns to geography and

126 environmental variables to assess their relative roles in shaping population divergence.

128 MATERIALS AND METHODS

\section{Sample collection}

131 To test for patterns of divergence related to geography and local adaptation in $C$.

132 violacea, we collected snails on snorkel or scuba at ten locations spanning a large portion

133 of the snail's geographic range (Table 1, Fig. 1). Sampled populations included both sides

134 of the Sunda Shelf, an area where phylogeographic structure is commonly observed, as

135 well as Hawai' $i$, the edge of $C$. violacea's geographic range and an area known to exhibit

136 peripheral isolation (Gaither et al., 2011b; Hodge et al., 2014). In addition, we only used

137 snails collected from $P$. lobata and $P$. compressa coral colonies (clades 2 and 3 , the

138 "green group" from Simmonds et al. 2018) that were previously DNA barcoded using

139 RAD-seq data. This selectivity was necessary because Porites corals are notoriously

140 challenging to identify in situ due to their morphological plasticity and small corallites

141 (Forsman et al., 2015) and because genetically similar colonies can have vastly different

142 morphologies and vice versa (Forsman et al., 2009). In total, we collected snails from 1-3

143 colonies at each location for a total of 71 snails from 32 coral colonies. A portion of each

144 snail's foot tissue was preserved in 95\% ethanol and stored at room temperature for DNA 145 analysis. 


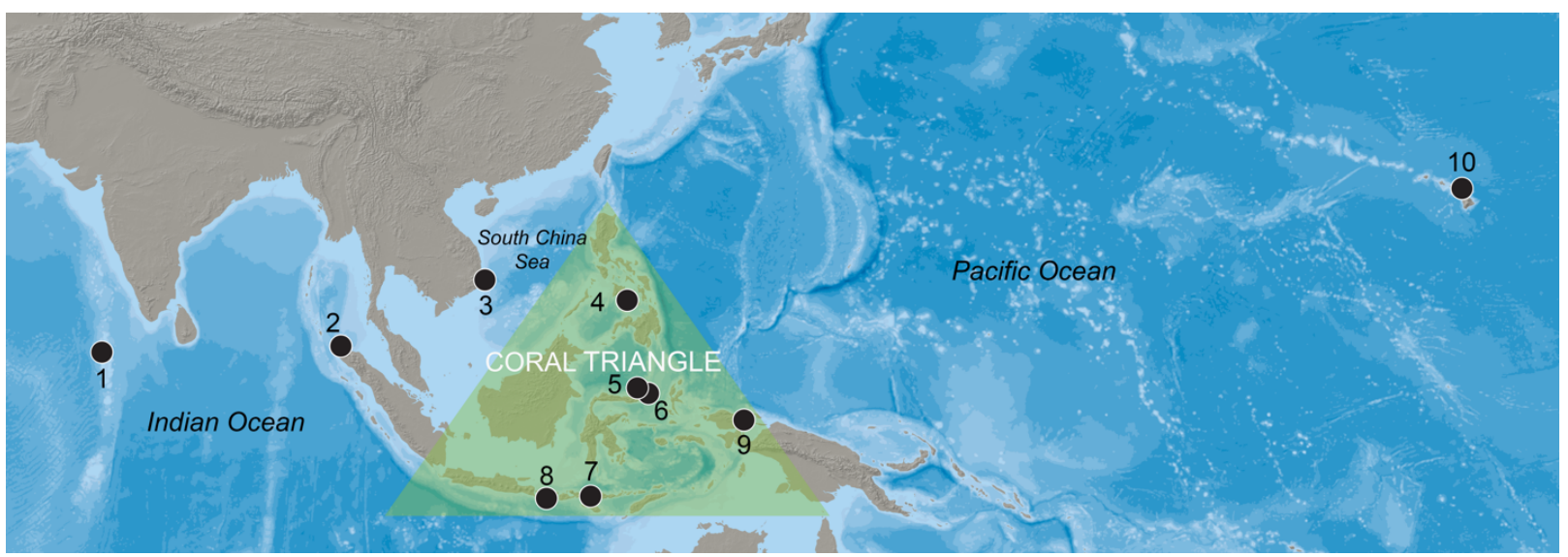

Figure 1 Map of Coralliophila violacea collection locations across the Indo-Pacific region. Sampled populations include 1. Vavvaru. 2. Pulau Weh 3. Hòn Mun 4. Dumaguete 5. Bunaken 6. Lembeh 7 Pulau Mengyatan 8. Nusa Penida 9. Manokwari 10. Ka'a'awa. Raster map made with Natural Earth.

Table 1 Sampling locations for Coralliophila violacea collected from coral hosts Porites lobata and $P$. compressa from Porites lineage 1, corresponding environmental variables from MARSPEC database for each location used in Bayenv2 analysis. Coordinates are in decimal degrees. Location numbers correspond to those in Figure 1. Regions were used for AMOVA analyses. Sea surface salinity (SSS) in psu (practical salinity units). Sea surface (SST) in ${ }^{\circ} \mathrm{C} . N=$ no. of individuals.

\begin{tabular}{|c|c|c|c|c|c|c|c|c|c|}
\hline LOCATION & COUNTRY & REGION & LATITUDE & LONGITUDE & $\begin{array}{l}\text { WARMEST MO. } \\
\text { SST }\end{array}$ & SST & SST RANGE & SSS & $\begin{array}{l}\text { SSS } \\
\text { RANGE }\end{array}$ \\
\hline 1. Vavvaru & Maldives & Indian Ocean & 5.419 & 73.358 & 29.42 & 28.37 & 1.76 & 34.93 & 1.64 \\
\hline 2. Pulau Weh & Indonesia & Indian Ocean & 5.887 & 95.348 & 29.39 & 28.59 & 1.40 & 33.29 & 1.43 \\
\hline 3. Hòn Mun & Vietnam & Vietnam & 12.170 & 109.308 & 28.20 & 26.45 & 4.22 & 33.34 & 0.77 \\
\hline 4. Dumaguete & Philippines & Coral Triangle & 9.332 & 123.312 & 28.54 & 27.61 & 3.16 & 33.96 & 0.92 \\
\hline 5. Bunaken & Indonesia & Coral Triangle & 1.612 & 124.783 & 28.74 & 28.34 & 1.05 & 33.95 & 0.79 \\
\hline 6. Lembeh & Indonesia & Coral Triangle & 1.479 & 125.251 & 28.81 & 27.87 & 2.94 & 33.95 & 0.85 \\
\hline 7. Pulau Mengyatan & Indonesia & Coral Triangle & -8.557 & 119.685 & 28.47 & 27.51 & 1.95 & 34.09 & 0.68 \\
\hline 8. Nusa Penida & Indonesia & Coral Triangle & -8.675 & 115.513 & 28.81 & 27.60 & 2.12 & 33.89 & 1.19 \\
\hline 9. Manokwari & Indonesia & Coral Triangle & -0.888 & 134.085 & 29.16 & 28.90 & 0.78 & 34.09 & 1.03 \\
\hline 10. Ka'a'awa & USA & Hawai ${ }^{\circ} i$ & 21.584 & -157.887 & 26.43 & 24.99 & 2.81 & 34.92 & 0.21 \\
\hline
\end{tabular}

\section{Creation of RAD-seq libraries}

159 We extracted DNA from $20 \mathrm{mg}$ of foot tissue using a Qiagen DNeasy Blood and Tissue

160 Kit (Qiagen). We followed the manufacturer's instructions, except in the last step, when

161 we eluted DNA with $100 \mu \mathrm{l}$ of molecular grade $\mathrm{H}_{2} \mathrm{O}$ rather than $\mathrm{AE}$ buffer. We estimated

162 initial DNA concentrations using a NanoDrop and visualized DNA quality on a 1\% 
163 agarose gel stained with SYBR Green. We used only high-quality DNA with a bright

164 high molecular weight band and minimal smearing. We dried DNA extractions using a

165 SpeedVac on medium heat and reconstituted using molecular grade $\mathrm{H}_{2} \mathrm{O}$ to a final

166 uniform $250 \mathrm{ng} / \mu 1 \mathrm{DNA}$ concentration.

167 We prepared 2b-RAD libraries following the protocol of Wang et al. (Wang et al., 168 2012). AlfI restriction enzymes digest reduced representation $\left(1 / 16^{\text {th }}\right)$ libraries labeled

169 with individual barcodes and subjected to 18-20 PCR amplification cycles. We

170 electrophoresed products on a $2 \%$ agarose gel in a $1 \times$ TBE buffer and run at $150 \mathrm{~V}$ for 90

171 minutes. Target bands (165 bp) were visualized with SYBR SAFE dye and excised from

172 the gel. The excised band was then purified using a QIAquick gel purification kit

173 (Qiagen). For a final cleaning step, we used Ampure XP beads (Beckman-Coulter). The

174 QB3 Vincent J. Coates Genomics Sequencing Laboratory at UC Berkeley conducted

175 quality checks (qPCR, BioAnalyzer) and sequencing of the resulting libraries,

176 multiplexing 10-20 snails per lane in 5 lanes of a $50 \mathrm{bp}$ single-end run on the Illumina

177 HiSeq 2000 platform.

178

179 RAD-seq data processing

180 To prepare raw sequence data for SNP identification, we truncated all raw reads to the

181 insert size (36 bp), filtered for quality (PHRED scores $>20$ ), and discarded empty

182 constructs. We used custom scripts to process the data, available on GitHub

183 https://github.com/z0on/2bRAD_denovo. First, unique tag sequences (minimum

184 sequencing depth $5 \times$ ) were counted, the number in reverse-complement orientation

185 recorded and merged into one table. All sequences were then clustered in CD-HIT using 
186 a 91\% similarity threshold. Next, we defined the reference as the most abundant sequence

187 in the cluster. We then filtered a locus-annotated table from the previous two steps,

188 excluding reads below $5 \times$ depth or exhibiting strand bias. The resulting clustered

189 sequences' orientation was then flipped to match the most abundant tag in a cluster.

190 We applied mild allele filters (10× total depth, allele bias, and strand bias), with the

191 requirement that alleles appear in at least two individuals. We then applied locus filters,

192 allowing a maximum of 50\% heterozygotes at a locus, no more than two alleles,

193 genotyped in $30 \%$ of samples, and polymorphic. The final set of SNPs was then thinned

194 to one per tag (the one with the highest minor allele frequency) for STRUCTURE

195 analysis and gene-environment association tests to remove linked loci that might be in

196 linkage disequilibrium.

198 Individual sample filtering steps

199 From the first 71 individuals, we filtered out those with low genotyping rates $(N=5)$, indicating

200 poor DNA quality by taking the $\log _{10}$ of the number of sites genotyped per individual and

201 removing individuals $\geq 2$ standard deviations $(\mathrm{SD})$ of the mean. We also removed individuals $(N$

$202=4)$ with high homozygosity (+/-2 SD of the mean $F$ inbreeding coefficient), indicating

203 potential contamination. We used the remaining 63 individuals in all analyses. The final data file

204 was in VCF format, and we converted it to other data formats using PGDSpider v2.1.0.1 (Lischer

$205 \&$ Excoffier, 2012).

\section{Genetic diversity}

208 We calculated basic population genetic summary statistics using all filtered loci for each location 
with ARLEQUIN v3.5 (Excoffier \& Lischer, 2010). We estimated the number and frequency of

210 polymorphic loci for each site, observed and expected heterozygosity, and genetic diversity

211 (averaged across all loci).

212

\section{$213 \boldsymbol{F}_{\text {ST }}$ outlier loci test}

214 We tested loci potentially under natural selection by identifying outlier $F_{\text {ST }}$ values using

215 BayeScan v2.1 (Foll \& Gaggiotti, 2008). We ran BayeScan with the data structured in two ways

216 to look for outliers at different spatial scales, 1) comparing individual localities and 2) comparing

217 localities grouped into regions (Table 1). We ran the data with a burn-in of 50,000, a thinning

218 interval 10, a sample size 5,000, 100,000 iterations, and 20 pilot runs of 5,000, each examining

219 two different false discovery rates $(\mathrm{FDR}=0.10,0.05)$

\section{$221 \quad$ Population genetic structure}

222 We used the Bayesian model-based clustering method STRUCTURE (Pritchard et al., 2000) to

223 infer the population genetic structure and individual admixture proportions. We examined three

224 datasets consisting of 63 individuals: 1) full RAD-seq dataset using all loci; 2) using only neutral

225 loci as determined by BayeScan; and 3) outlier loci with a false discovery rate of $10 \%$ (FDR =

226 0.10, BayeScan). We ran STRUCTURE with a burn-in period of 20,000 followed by 50,000

227 MCMC replicates for $K=1-10$, and ten runs for each $K$. We used the admixture model, with

228 allele frequencies correlated among populations. We selected the optimal value of $K$ using the

$229 \Delta K$ statistic (Evanno et al., 2005) and summarized the results graphically using the program

230 CLUMPAK v1.1 (Kopelman et al., 2015). To test for the significance of genetic partitions

231 identified by STRUCTURE, we ran analyses of molecular variance (AMOVA), both with and 
232 without regional groupings (Table 1). We determined significance by 100,000 random replicates 233 in ARLEQUIN.

\section{Genetic-environment association tests}

236 Because ocean climate variables that impact species distributions (Briggs, 2006) may also

237 structure population genetics (Sanford \& Kelly, 2011), we examined differences in allele

238 frequencies associated with environmental variables using a Bayesian framework (Bayenv 2.0;

239 (Coop et al., 2010; Günther \& Coop, 2013) that accounts for demographic history. First, we

240 obtained ocean environmental variables from the MARSPEC database (Sbrocco \& Barber,

241 2013). Because of strong correlations among environmental variables, we selected only five in

242 the MARSPEC database for analysis: 1) temperature of the warmest ice-free month (biogeo15),

243 2) mean annual sea surface temperature (annual sea surface temperature; biogeo13), 3) annual

244 range in sea surface temperature (biogeo16), 4) mean annual sea surface salinity (biogeo08), and

245 5) annual range in sea surface salinity (biogeo11). Temperature variables are particularly

246 important to this system because coral reefs in locations with high sea surface temperatures are

247 most likely to be impacted by coral bleaching events (Hoegh-Guldberg, 1999). Thus, coral

248 mortality from bleaching could directly impact $C$. violacea living on coral hosts and indirectly by

249 limiting the number and species of hosts available to C. violacea in affected reefs.

250 To create maps of each of the five environmental variables across the study region, we

251 projected the annual mean and range of sea surface salinity (SSS) and temperature (SST), plus

252 the mean warmest monthly temperature at $\sim 5 \mathrm{~km}$ resolution onto an equidistant cylindrical world

253 using the 'raster' package in R. Then, we extracted the five climate variable data to each point

254 location and divided it by a scaling factor of 100 using custom R scripts. Next, we estimated a 
covariance matrix with standardized environmental variables for each sampling location, as suggested by the authors of Bayenv2 (Coop et al., 2010; Günther \& Coop, 2013), and 3,186 loci

257 that were polymorphic among all sites, for 100,000 iterations, outputting the results every 500

258 iterations. Finally, we used the last printed covariance matrix for all further analyses. To estimate

259 the Bayes Factor (BF) for each SNP with each ocean climate variable, we ran Bayenv2 for

260 100,000 Markov chain Monte Carlo (MCMC) iterations. For each ocean climate variable, SNPs

261 with $\log _{10} \mathrm{BF}>1$ were considered to give substantial-to-strong support for environmentally-

262 associated loci, based on criteria from (Litton \& Jefferys, 1984).

\section{Candidate gene annotation}

265 To annotate the function of genes linked to outlier loci and environmentally-associated loci, we 266 aligned sequences containing outlier loci to nucleotides (nr/nt) on the NCBI website using the

267 BLASTN algorithm at two different taxonomic levels, 1) Mollusca (taxid:6447) and 2)

268 Lophotrochozoa (taxid:1206795). We adjusted parameters (word size 7, expected threshold 10, 269 no mask for lookup table, no low complexity filter) to accommodate short-read sequences. We 270 only examined hits with a high percent query coverage ( $>85 \%)$ and used NCBI to identify and 271 annotate any associated genes.

\section{RESULTS}

274 The average number of unique reads per individual was 6.6 million at minimum $5 \times$ depth after 275 filtering for quality and removing empty constructs. We sequenced and genotyped 46,148 high276 quality RAD-seq loci with $\geq 25 \times$ coverage in 71 individuals at ten locations. First, we filtered the 277 dataset for 30\% maximum missing data per locus, leaving 7,862 loci, and then thinned to one 
278 SNP per loci to remove any physically linked SNPs for STRUCTURE and $F_{\mathrm{ST}}$ analyses, leaving

2793,188 SNPs. Next, we removed nine individuals with potential contamination issues (inbreeding

280 coefficient $\geq+2$ SD from the mean) or low DNA quality (missing data $\geq+1$ SD from the mean),

281 leaving 63 individuals.

282

\section{Genetic diversity}

284 Across all locations, a mean of $47 \%$ of loci were polymorphic. Hòn Mun in Vietnam had the 285 highest frequency of polymorphic loci (81\%) and the most sequenced individuals (Table 2).

286 Observed heterozygosity $\left(\mathrm{H}_{\mathrm{O}}=0.196-0.570\right)$ and expected heterozygosity $\left(\mathrm{H}_{\mathrm{E}}=0.225-0.586\right)$

287 varied across locations, but $\mathrm{H}_{\mathrm{O}}$ was consistently lower than the $\mathrm{H}_{\mathrm{E}}$ at every location (Table 2).

288 Mean genetic diversity over all loci across sites was 0.122 , and genetic diversity varied across

289 locations (0.089-0.162; Table 2). Genetic diversity was highest in Dumaguete (0.162) and

290 lowest in Bunaken (0.095) (Table 2).

292 Table 2 Standard diversity indices and summary statistics for all 3,188 loci obtained from 293 Coralliophila violacea. $N=$ no. of individuals, no. of polymorphic loci per location, frequency of 294 polymorphic loci, observed heterozygosity $\left(\mathrm{H}_{\mathrm{O}}\right)$, expected heterozygosity $\left(\mathrm{H}_{\mathrm{E}}\right)$, and gene diversity 295 over all loci.

\begin{tabular}{lcccccc} 
Location & $\boldsymbol{N}$ & $\begin{array}{c}\text { No. poly. } \\
\text { loci }\end{array}$ & $\begin{array}{c}\text { Freq. poly. } \\
\text { loci }\end{array}$ & $\mathbf{H}_{\mathbf{0}}$ & $\mathbf{H}_{\mathbf{E}}$ & $\begin{array}{c}\text { Gene } \\
\text { diversity }\end{array}$ \\
\hline 1. Vavvaru & 4 & 1293 & $41 \%$ & 0.345 & 0.449 & 0.104 \\
2. Pulau Weh & 3 & 1051 & $33 \%$ & 0.459 & 0.544 & 0.103 \\
3. Hòn Mun & 19 & 2598 & $81 \%$ & 0.196 & 0.225 & 0.159 \\
4. Dumaguete & 2 & 1022 & $32 \%$ & 0.570 & 0.586 & 0.162 \\
5. Bunaken & 7 & 1577 & $49 \%$ & 0.281 & 0.342 & 0.095 \\
6. Lembeh & 6 & 1515 & $48 \%$ & 0.301 & 0.341 & 0.114 \\
7. Pulau Mengyatan & 4 & 1143 & $36 \%$ & 0.360 & 0.463 & 0.089 \\
8. Nusa Penida & 9 & 1881 & $59 \%$ & 0.271 & 0.296 & 0.115 \\
9. Manokwari & 5 & 1680 & $53 \%$ & 0.274 & 0.357 & 0.149 \\
10. Ka'a'awa & 4 & 1229 & $39 \%$ & 0.353 & 0.397 & 0.132 \\
\hline
\end{tabular}




\section{Gene flow and genetic structure}

299 Results from STRUCTURE using the full dataset of 3,188 loci or just 3,116 putatively neutral

300 loci confirmed that $K=4$ was the best-supported number of population partitions (Evanno et al.

301 2005). The four genetic partitions corresponded to recognized distinct biogeographic regions: a)

302 Indian Ocean (1. Vavvaru, 2. Pulau Weh); b) Vietnam (3. Hòn Mun); c) the Coral Triangle (4.

303 Dumaguete, 5. Bunaken, 6. Lembeh, 7. Pulau Mengyatan, 8. Nusa Penida and 9. Manokwari);

304 and d) Hawai'i (10. Ka'a’awa) (Fig. 2). Levels of admixture among these regions were variable.

305 Hawai' $i$ and Vietnam showed minimal admixture from other locations. In contrast, sites in the

306 Indian Ocean had the highest levels of admixture, with numerous individuals exhibiting a mix of

307 alleles from the Indian Ocean and populations to the east. Specifically, Pulau Weh exhibited

308 substantial admixture with the Coral Triangle, and Vavvaru in the Maldives had admixture from

309 both Vietnam and the Coral Triangle. Levels of admixture varied across sites in the Coral

310 Triangle. Pulau Mengyatan and Manokwari had the highest levels, while Dumaguete, Bunaken,

311 Lembeh, and Nusa Penida had the lowest; admixture in these populations was mainly from the

312 Indian Ocean and Vietnam. Results were virtually identical whether we used all loci or neutral

313 loci. 


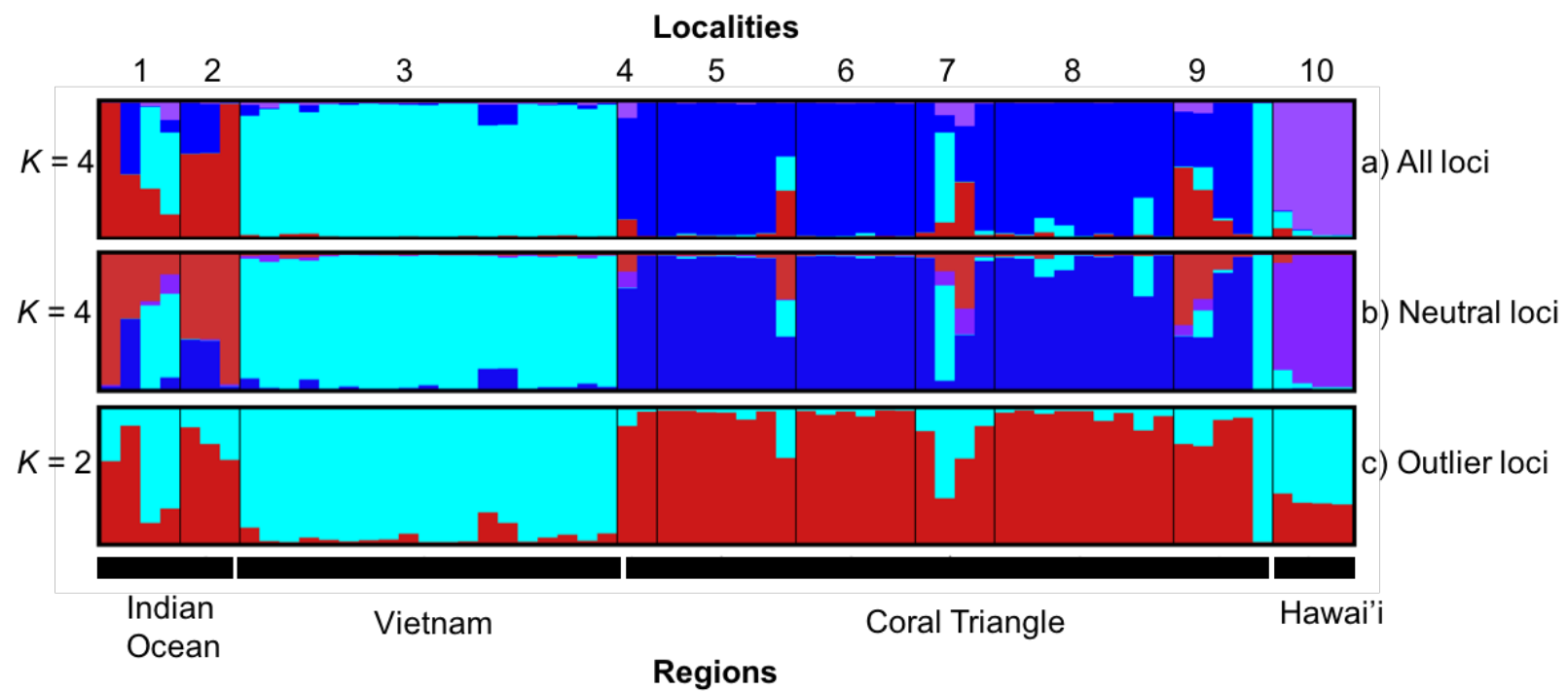

Figure 2 Patterns of genetic structure in Coralliophila violacea in the Indo-Pacific region. CLUMPAK-averaged STRUCTURE plots for ten independent runs, clustered and average using CLUMPAK. Each bar represents an individual, and the color is the proportion of assignment to each genetic partition. Locations plotted from left to right and numbered above, and black bars indicate regions as in Table 3.1 a) all 3,188 loci at $K=4$, b) 3,116 neutral loci at $K=4$, c) 72 outlier loci at $K=2$.

Consistent with STRUCTURE results, AMOVA analyses showed significant population structure across all loci (overall $F_{\mathrm{ST}}=0.071, \mathrm{p}>0.001$ ). Hòn Mun in Vietnam was isolated from all other locations (pairwise $F_{\mathrm{ST}}=0.063-0.147$; Table 3) except Pulau Mengyatan in southern Indonesia. Ka'a'awa in Hawai'i was also strongly divergent from four other locations (pairwise $F_{\mathrm{ST}}=0.142-0.235 ;$ Table 3). Similarly, Pulau Weh in the Indian Ocean was different from all locations (pairwise $F_{\mathrm{ST}}=0.021-0.168$; Table 3) except for Vavvaru in the Maldives,

Dumaguete in the Philippines, and Ka'a'awa in Hawai'i. AMOVA analyses grouping sites into four biogeographic regions (Indian Ocean, South China Sea, Coral Triangle, Hawai'i; Table 1, Fig. 3) increased the overall $F_{\mathrm{ST}}$ to $0.098(\mathrm{p}>0.001)$, and the $F_{\mathrm{CT}}$ was $0.109(\mathrm{p}>0.001)$.

However, regional variation only accounted for $10 \%$ of the overall variation, and the majority $(90 \%)$ was within populations (Table 4$)$. 
333 Table 3 Genetic distances of pairwise populations of Coralliophila violacea for all 3,188 SNPs.

334 Regions follow labeling in Table 1.1. Significant pairwise $F_{\text {ST }}$ values at $p>0.01(\alpha=0.05$, corrected

335 for multiple tests using the B-Y method, (Narum, 2006) are shaded.

\begin{tabular}{|c|c|c|c|c|c|c|c|c|c|c|}
\hline \multirow[b]{2}{*}{ Location } & \multicolumn{2}{|c|}{ Indian Ocean } & \multirow{2}{*}{$\begin{array}{c}\text { Vietnam } \\
3 \\
\end{array}$} & \multicolumn{6}{|c|}{ Coral Triangle } & \multirow{2}{*}{$\begin{array}{c}\text { Hawai' } \mathbf{i} \\
10 \\
\end{array}$} \\
\hline & 1 & 2 & & 4 & 5 & 6 & 7 & 8 & 9 & \\
\hline 1. Vavvaru & 0 & & & & & & & & & \\
\hline 2. Pulau Weh & -0.026 & 0 & & & & & & & & \\
\hline 3. Hòn Mun & 0.014 & 0.034 & 0 & & & & & & & \\
\hline 4. Dumaguete & 0.063 & 0.021 & 0.122 & 0 & & & & & & \\
\hline 5. Bunaken & 0.068 & 0.072 & 0.067 & 0.011 & 0 & & & & & \\
\hline 6. Lembeh & 0.085 & 0.077 & 0.109 & 0.008 & 0.007 & 0 & & & & \\
\hline 7. Pulau Mengyatan & 0.022 & 0.033 & -0.004 & -0.025 & -0.005 & 0.002 & 0 & & & \\
\hline 8. Nusa Penida & 0.059 & 0.052 & 0.098 & 0.013 & 0.000 & 0.011 & -0.020 & 0 & & \\
\hline 9. Manokwari & -0.005 & -0.022 & 0.063 & 0.020 & -0.011 & 0.024 & -0.050 & 0.024 & 0 & \\
\hline 10. Ka'a'awa & 0.157 & 0.168 & 0.147 & 0.217 & 0.221 & 0.235 & 0.142 & 0.223 & 0.164 & 0 \\
\hline
\end{tabular}

336 Table 4 Hierarchical AMOVA of Coralliophila violacea populations sampled across all 3,188 loci with locations grouped by region as indicated in Table 1 . Significant $F$-statistic values at $p>0.001$

338 are in boldface.

\begin{tabular}{lcll}
\hline Source of variation & $\boldsymbol{F}$-statistics & P-values & $\mathbf{\%} \mathbf{3}$ var. \\
\hline Among regions & $\boldsymbol{F}_{\mathrm{CT}}=\mathbf{0 . 1 0 9}$ & $<0.001$ & 10.93 \\
Among populations & $F_{\mathrm{SC}}=-0.012$ & 0.389 & $-\mathbf{1}_{\mathbf{3}} 091$ \\
Within populations & $\boldsymbol{F}_{\mathrm{ST}}=\mathbf{0 . 0 9 8}$ & $<0.001$ & 90.16 \\
\hline
\end{tabular}




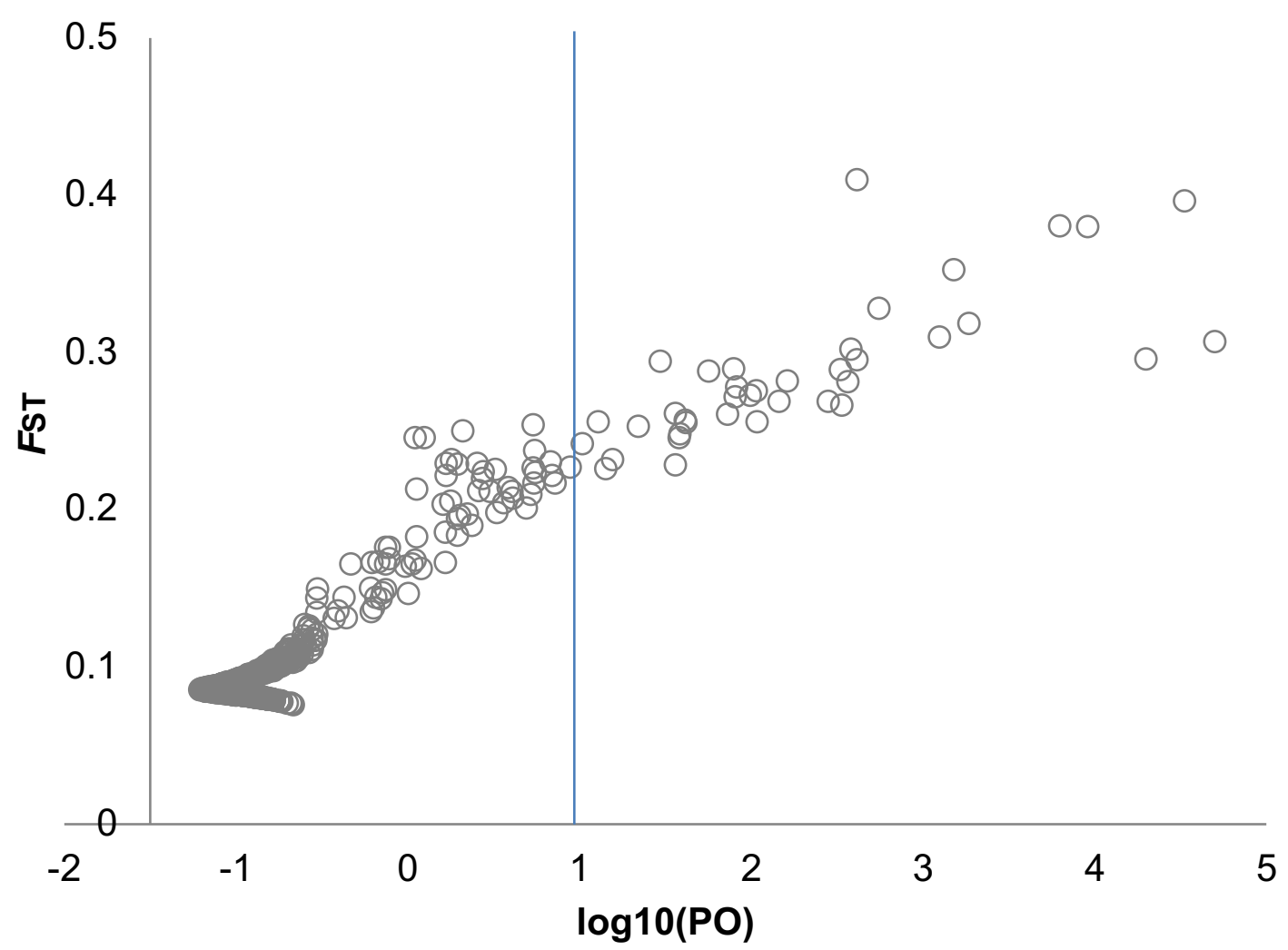

342

343

344

345

346

347

348

349

350

351

352

353

354

Figure 3 Outlier loci among sampled populations of Coralliophila violacea as identified by BayeScan. Points to the right of the blue line are outliers.

\section{Outlier tests}

Using a false discovery rate (FDR) of 10\%, BayeScan revealed 72 outlier loci putatively under directional selection among all locations $(\mathrm{FDR}=0.10,72 ; \mathrm{FDR}=0.05,57)$, and 34 outlier loci among regions (Indian Ocean, Vietnam, Coral Triangle, Hawai ‘i; FDR = 0.10, 34; FDR = 0.05, 25) (Fig. 4). Considering only these 72 outlier loci, STRUCTURE indicated that $K=2$ was the best-supported number of genetic partitions (Fig. 2). In contrast to results from all loci or just neutral loci above, the two genetic partitions identified using only outlier loci do not correspond to individual sites. Instead, results recover two groups: 1) Hòn Mun, Vietnam and Ka'a'awa, Hawai' $i$, two locations separated by $\sim 9,800 \mathrm{~km}$ of open ocean, and 2) all other sites (Fig. 2). 

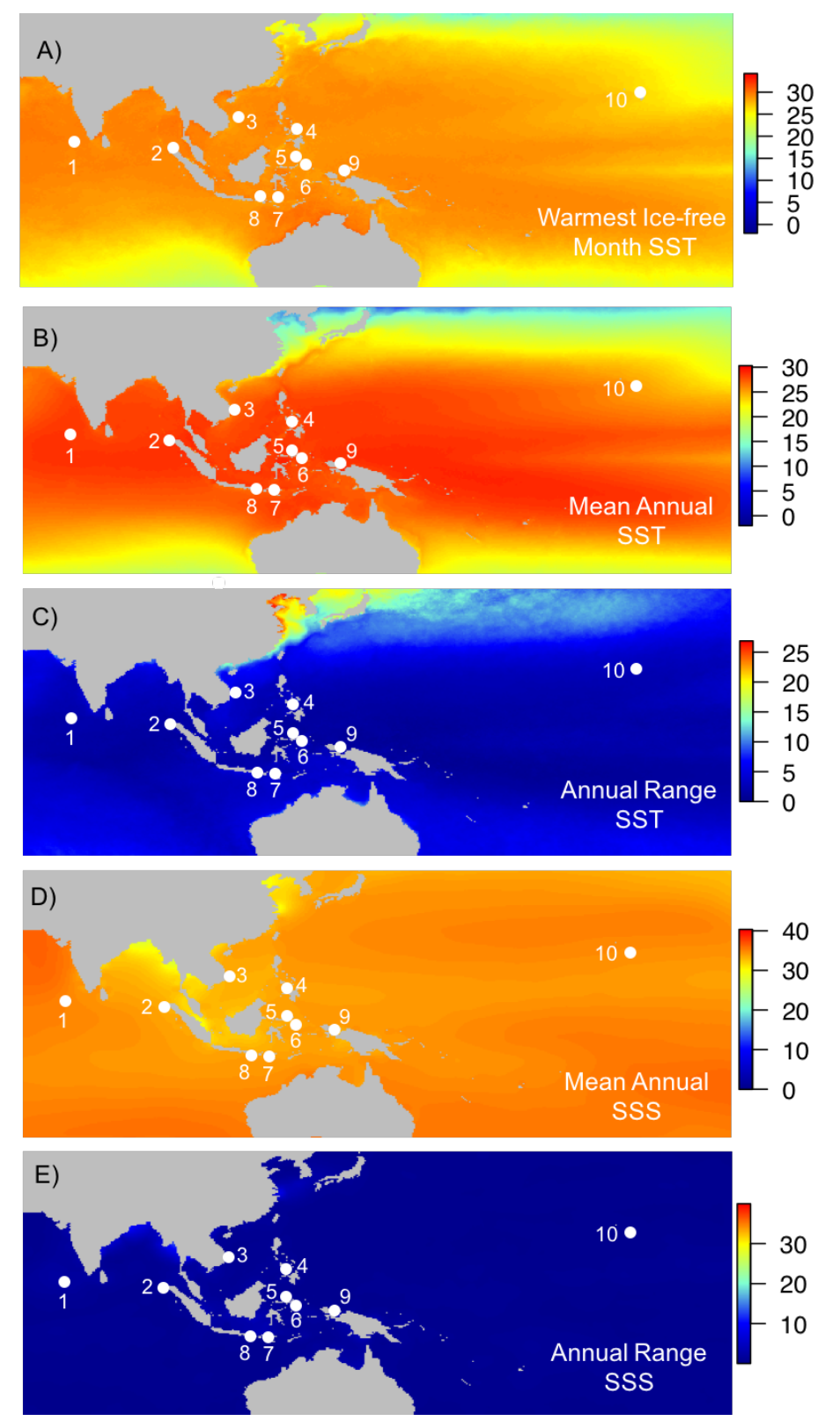

Figure 4 Ocean climate variables a) temperature of the warmest ice-free month, b) annual mean, 359 and c) range of sea surface temperature $(\mathrm{SST})$ in $\left.{ }^{\circ} \mathrm{C}, \mathbf{d}\right)$ annual mean, and e) range of sea surface 360 salinity (SSS) in psu. Data source MARSPEC (Sbrocco \& Barber, 2013).

\section{Ocean climate variables and associations with allele frequency differences}

363 Results from MARSPEC show significant variation in the five environmental variables across

364 the sampled region. The temperature of the warmest ice-free month varied by more than $3{ }^{\circ} \mathrm{C}$ 
across the sampled sites, with the highest temperature in the Indian Ocean $\left(\sim 29.4{ }^{\circ} \mathrm{C}\right)$ and lowest in Hawai'i $\left(26.4{ }^{\circ} \mathrm{C}\right)$ and Vietnam $\left(28.2^{\circ} \mathrm{C}\right)$ (Table 1, Fig. 4a). The mean annual sea surface temperature (SST) also varied substantially across sampling locations by $\sim 4{ }^{\circ} \mathrm{C}$ (Table 1 , Fig. 4a). However, in this case, Manokwari $\left(28.90{ }^{\circ} \mathrm{C}\right)$ and Pulau Weh $\left(28.59{ }^{\circ} \mathrm{C}\right)$ at the edges of Indonesia were the warmest, while again Hawai' ${ }^{\prime}\left(24.99{ }^{\circ} \mathrm{C}\right)$ and Vietnam $\left(26.45^{\circ} \mathrm{C}\right)$ were the

370 coldest locations (Table 1, Fig. 4a). SST at some sites was very stable, with only small annual 371 ranges: Manokwari $\left(0.78^{\circ} \mathrm{C}\right)$ and Bunaken $\left(1.05^{\circ} \mathrm{C}\right)$. At other locations, SST varied more widely 372 (e.g., Dumaguete $\left(3.16^{\circ} \mathrm{C}\right)$ and Vietnam $\left(4.22^{\circ} \mathrm{C}\right)$; Table 1, Fig. $\left.4 b\right)$. Sea surface salinity (SSS) also showed variation across sampling locations (Table 1, Fig. 2.5c). Sites in the two oceanic archipelagos, Vavvaru, Maldives (34.93 psu), and Ka'a'awa, Hawai'i (34.92 psu), had the highest values. In contrast, salinity at sites in the Coral Triangle was consistently lower (33.89 - 34.09 psu) (Table 1, Fig. 4c). Locations also experienced annual variation in salinity with inputs from freshwater runoff and precipitation (Fig. 4d). Sites in the Indian Ocean, Vavvaru (SSS range $=1.64 \mathrm{psu})$, and Pulau Weh $(\mathrm{SSS}$ range $=1.43 \mathrm{psu})$ had the most variable salinity while Ka'a'awa $(\mathrm{SSS}$ range $=0.21 \mathrm{psu})$ in Hawai' $i$ was the most stable (Table 1, Fig. 4d).

We identified a total of 88 SNPs using Bayenv2, for which allele frequency differences correlated with one or more of the five ocean climate variables (Fig. 5). The greatest proportion

383 of these 88 SNPs were associated with annual temperature range $(N=38)$, followed by mean 384 annual temperature $(N=31)$, temperature of the warmest ice-free month $(N=21)$, annual range 385 of salinity $(N=12)$ and mean annual salinity $(N=10)$ (Fig. 5). SNPs associated with temperature 386 had the highest Bayes Factors (Fig. 5). Of these, 22 SNPs were associated with more than one 387 variable $(N=20$ with two variables, $N=2$ with three variables). The warmest month's mean SST 
390 with environmental variables and the 72 outlier loci.

\section{A) SST warmest ice-free month}
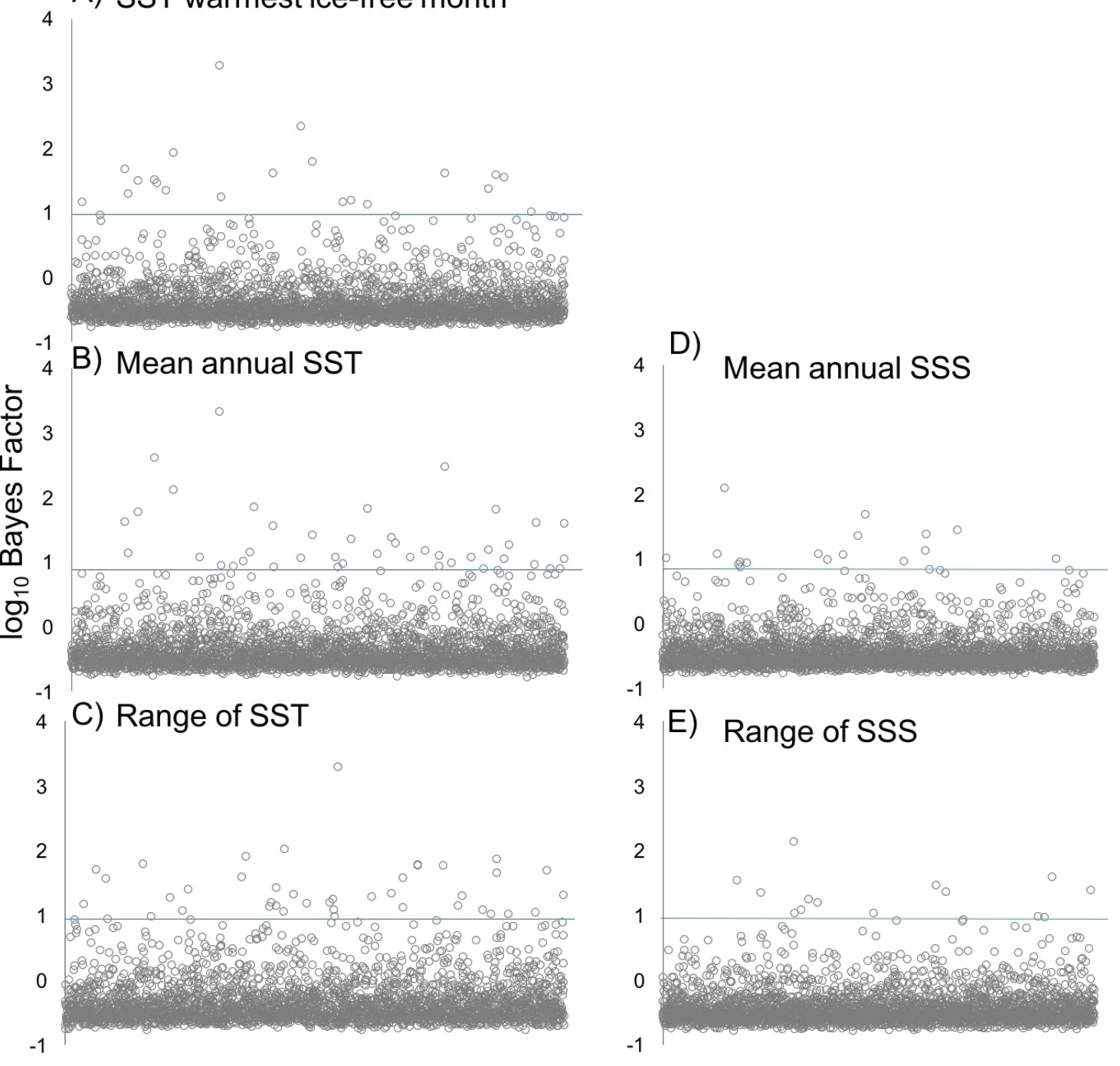

Figure 5 Bayenv2 association of allele frequencies for all polymorphic loci $(3,186)$ with each ocean climate variable. SNPs are ordered by tagID. Blue line indicates significance level above which loci are considered to associate with climate variables (Jeffreys, 1998) strongly.

\section{Mapping and annotation of outliers and environmentally-associated loci}

For loci significantly associated with environmental variables, the majority $(49 / 87 ; 56 \%)$

did not map to any mollusc or lophotrochozoan sequences available in the NCBI database 
399 (Table 5). However, we were able to align the other 43\% (38/88) of candidate loci to

400 DNA sequences from a variety of molluscs, including an octopus (Octopus vulgaris),

401 oysters (Crassostrea gigas, C. virginica), scallops (Pecten maximus, Mizuhopecten

402 yessoensis, Azumapecten farrei), a clam (Scapharca broughtonii), and four marine snails

403 (Conus episcopatus, C. ximenes, Thais clavigera, Nucella lapillus) and two freshwater

404 snails (Pomacea canaliculata, Biomphalaria glabrata). Of these loci, 19 loci were

405 mapped to protein-coding regions. Six of these loci coded for uncharacterized proteins,

406 two microsatellites, and the other 11 were characterized with annotated functions (Table

407 5).

$408 \quad$ For outlier loci identified by BayeScan, nearly half (47\%; 34/72) mapped to

409 molluscs in the NCBI database, including an octopus (Octopus pallidus), oysters

410 (Crassostrea gigas, C. virginica), a scallop (Pecten maximus), a sea hare (Aplysia

411 californica), a limpet (Lottia gigantea), a freshwater snail (Pomacea canaliculata) and

412 marine snail (Conus episcopatus) ( Table 5). Of these loci, ten had associated predicted

413 protein functions. The top two outlier loci, in terms of percent identity of sequences and

414 the lowest E-value, aligned with a conotoxin from a cone snail (Conus episcopatus) and a

415 gene (CAPLA) coding for a protein involved in behavioral plasticity in the California

416 seahare (Aplysia californica). Interestingly, despite no overlap between the 72 outlier loci

417 identified by BayeScan and the 88 environmentally-associated loci identified by

418 Bayenv2, both sets contained loci mapped to genes coding for conotoxins (Table 5). 
419 Table 5 Annotations for BayeScan outlier loci among sites and Bayenv2 environmentally-

420 associated loci mapped to DNA sequences in the NCBI database.

\begin{tabular}{|c|c|c|c|c|c|c|c|c|}
\hline \multicolumn{9}{|c|}{ BAYESCAN } \\
\hline Tag & Sequence & Organism & Description & Score & E-value & Identity & Gene & GO functions \\
\hline 27523 & $\begin{array}{l}\text { CGTATGCCGTCTTCTGCTTGA } \\
\text { AAAAAAAAAAAATAC }\end{array}$ & Conus episcopatus & conotoxin gene & 55.4 & $2.00 \mathrm{E}-07$ & $97 \%$ & & conotoxin \\
\hline 29969 & $\begin{array}{l}\text { AGGACCTGCTACGCAAGCTG } \\
\text { CTGCAGGTGGACCTCA }\end{array}$ & Aplysia californica & CAPL-A & 53.6 & $9.00 \mathrm{E}-07$ & $94 \%$ & CAPL-A & $\begin{array}{l}\text { ATP binding, protein } \\
\text { serine/threonine kinase activity, } \\
\text { behavior plasticity, learning and } \\
\text { memory }\end{array}$ \\
\hline 19005 & $\begin{array}{l}\text { GGAGAGTGTGATGCAGCCAT } \\
\text { CTGCAGTGTCTTTGCA }\end{array}$ & Coralliophila abbreviata & microsatellite & 37.4 & 0.019 & $97 \%$ & & \\
\hline 18735 & $\begin{array}{l}\text { TGAGATGATCTTGCAACCAC } \\
\text { ATGCCTCCATCCCTCT }\end{array}$ & Aplysia californica & $\begin{array}{l}\text { striatin-interacting } \\
\text { protein 1-like }\end{array}$ & 35.6 & 0.066 & $94 \%$ & STRIP1 & $\begin{array}{l}\text { protein binding, regulation of } \\
\text { cell morphogenesis, cortical } \\
\text { actin cytoskeleton organization }\end{array}$ \\
\hline 19841 & $\begin{array}{l}\text { TGCTTCTGTGGTGCAGGCCA } \\
\text { GTGCAAGACCTCAGTC }\end{array}$ & Biomphalaria glabrata & $\begin{array}{l}\text { zinc finger ZZ-type } \\
\text { and EF-hand domain- } \\
\text { containing protein 1- } \\
\text { like }\end{array}$ & 31.9 & 0.8 & $91 \%$ & $Z Z E F 1$ & calcium and zinc ion binding \\
\hline 30344 & $\begin{array}{l}\text { CACTGTGCCAAGGCATGGTA } \\
\text { TTGCAAGGGGGAGCCC }\end{array}$ & Aplysia californica & $\begin{array}{l}\text { E3 ubiquitin-protein } \\
\text { ligase DTX4-like }\end{array}$ & 30.1 & 2.8 & $86 \%$ & DTX4 E3 & ligase activity, zinc ion binding \\
\hline 36204 & $\begin{array}{l}\text { AGATCAACAGGGGCATCTCT } \\
\text { TTGCTCGGTAAAGTCC }\end{array}$ & Aplysia californica & protein FAM193A-like & 30.1 & 2.8 & $86 \%$ & FAM193A & uncharacterized protein \\
\hline 32125 & $\begin{array}{l}\text { AGTAATATGAGTGCATTTAG } \\
\text { TTGCAGGAGTCGTGTG }\end{array}$ & Aplysia californica & $\begin{array}{l}\text { epidermal retinol } \\
\text { dehydrogenase 2-like }\end{array}$ & 30.1 & 2.8 & $86 \%$ & SDR16C5 & $\begin{array}{l}\text { detection of light stimulus } \\
\text { involved in visual perception, } \\
\text { retinol dehydrogenase activity, } \\
\text { keratinocyte proliferation, } \\
\text { retinal and retinol metabolism }\end{array}$ \\
\hline 26718 & $\begin{array}{l}\text { AGCAGGACAATGCCATACCT } \\
\text { TGAAGCAGGACAATGC }\end{array}$ & Biomphalaria glabrata & $\begin{array}{l}\text { chitin biosynthesis } \\
\text { protein CHS5-like }\end{array}$ & 28.3 & 9.7 & $94 \%$ & CHS5 & chitin biosynthesis \\
\hline 36113 & $\begin{array}{l}\text { GACAGCCATCTCGCATAGTT } \\
\text { CTGCTGTTCCAGAGCA }\end{array}$ & Crassostrea gigas & complete sequence & 33.7 & 0.39 & $86 \%$ & & \\
\hline 53661 & $\begin{array}{l}\text { AGTCAAAGCATTGCAGATGT } \\
\text { CTGCTATCAAACTTCT }\end{array}$ & Lottia gigantea & hypothetical protein & 33.7 & 0.23 & $91 \%$ & & \\
\hline 40104 & $\begin{array}{l}\text { TATATAGAACAAGCAGCAAG } \\
\text { ATGCACAAGAGAAGCT }\end{array}$ & Lottia gigantea & hypothetical protein & 31.9 & 0.8 & $88 \%$ & & \\
\hline 36681 & $\begin{array}{l}\text { TAGTCATCAACAGCATTACA } \\
\text { CTGCCATCATTACATG }\end{array}$ & Biomphalaria glabrata & uncharacterized & 30.1 & 2.8 & $86 \%$ & & \\
\hline 48982 & $\begin{array}{l}\text { GGCTGATGGCTTGCATTATTC } \\
\text { TGCTTTATACTTCCT }\end{array}$ & Bellamya aeruginosa & microsatellite & 30.1 & 2.8 & $86 \%$ & & \\
\hline 30094 & $\begin{array}{l}\text { CACACACCAGAGGCAGGCAC } \\
\text { GTGCACGAGCATACCT }\end{array}$ & Biomphalaria glabrata & uncharacterized & 30.1 & 2.8 & $94 \%$ & & \\
\hline \multicolumn{9}{|c|}{ BAYENV2 } \\
\hline Tag & Sequence & Organism & Description & Score & E-value & Identity & Gene & GO functions \\
\hline 32340 & $\begin{array}{l}\text { TGTGTTTTTCTTGCATCGCAA } \\
\text { TGCATTGTCAATGAG }\end{array}$ & Aplysia californica & $\begin{array}{l}\text { rho GTPase-activating } \\
\text { protein } 17 \text {-like }\end{array}$ & 37.4 & 0.032 & $91 \%$ & ARHGAP17 & \multirow{2}{*}{$\begin{array}{l}\text { GTPase activator activity, signal } \\
\text { transduction } \\
\text { embryonic development, } \\
\text { meiotic mismatch repair, DNA }\end{array}$} \\
\hline 13973 & $\begin{array}{l}\text { TGTTCACTGACGGCAAAAGT } \\
\text { ATGCAAAATGAGGTCA }\end{array}$ & Biomphalaria glabrata & $\begin{array}{l}\text { DNA mismatch repair } \\
\text { protein Msh2-like }\end{array}$ & 30.1 & 4.8 & $94 \%$ & MSH2 & \\
\hline
\end{tabular}




\begin{tabular}{|c|c|c|c|c|c|c|c|c|}
\hline & & & & & & & & $\begin{array}{l}\text { phosphorylation, immune } \\
\text { response }\end{array}$ \\
\hline 14160 & $\begin{array}{l}\text { TGCTCTGAAGGCGCATTGTTT } \\
\text { TGCATTTAATTGACC }\end{array}$ & Biomphalaria glabrata & $\begin{array}{l}\text { ubiquitin carboxyl- } \\
\text { terminal hydrolase } 44- \\
\text { like }\end{array}$ & 33.7 & 0.39 & $86 \%$ & USP44 & $\begin{array}{l}\text { cell division, protein } \\
\text { deubiquitination, mitotic nuclear } \\
\text { division }\end{array}$ \\
\hline 26516 & $\begin{array}{l}\text { GGCGTTCTGTATGCACTTTCT } \\
\text { TGCTTCAGTTCTCCT }\end{array}$ & Biomphalaria glabrata & $\begin{array}{l}\text { coiled-coil domain- } \\
\text { containing protein } 94- \\
\text { like }\end{array}$ & 31.9 & 1.4 & $88 \%$ & Ccdc94 & protein binding \\
\hline 31366 & $\begin{array}{l}\text { AGATCGGAAGAGCACATGTC } \\
\text { TGAACTCCAGTCACGA }\end{array}$ & Conus episcopatus & conotoxin & 53.6 & 4.00E-07 & $88 \%$ & & conotoxin \\
\hline 23643 & $\begin{array}{l}\text { TGTTTTGGGGGAGCATGTCCC } \\
\text { TGCACACATACCCCT }\end{array}$ & Crassostrea gigas & $\begin{array}{l}\text { calcium-transporting } \\
\text { ATPase type } 2 \mathrm{C} \\
\text { member 1-like }\end{array}$ & 30.1 & 4.8 & $86 \%$ & $A T P 2 C 1$ & $\begin{array}{l}\text { calcium and manganese ion } \\
\text { transport, metabolic process, } \\
\text { signal transduction }\end{array}$ \\
\hline 33972 & $\begin{array}{l}\text { TGGGACAGGATTGCAACTTC } \\
\text { TTGCCTCAACAGATCT }\end{array}$ & Crassostrea gigas & $\begin{array}{l}\text { ankyrin repeat domain- } \\
\text { containing protein } 24- \\
\text { like }\end{array}$ & 30.1 & 4.8 & $94 \%$ & ANKRD24 & protein binding \\
\hline 33093 & $\begin{array}{l}\text { TAAGGAATGACAGCAAACCA } \\
\text { ATGCTACCTCTCCTCT }\end{array}$ & Octopus bimaculoides & exonuclease 1-like & 30.1 & 4.8 & $100 \%$ & EXOI & $\begin{array}{l}\text { immune response, DNA repair, } \\
\text { mismatch repair, double-strand } \\
\text { break repair }\end{array}$ \\
\hline 31520 & $\begin{array}{l}\text { CGCACGAACTACGCACACTC } \\
\text { ATGCATACAAATCATC }\end{array}$ & Octopus bimaculoides & $\begin{array}{l}\text { little elongation } \\
\text { complex subunit 2-like }\end{array}$ & 33.7 & 0.39 & $88 \%$ & ICE 2 & snRNA transcription regulation \\
\hline 30745 & $\begin{array}{l}\text { GGGCTCTGTCTCGCAATACC } \\
\text { GTGCTCAGATAAAGTG }\end{array}$ & Octopus bimaculoides & $\begin{array}{l}\text { A-kinase anchor } \\
\text { protein } 10 \text {, } \\
\text { mitochondrial-like }\end{array}$ & 31.9 & 1.4 & $88 \%$ & $A K A P 10$ & $\begin{array}{l}\text { blood coagulation, signal } \\
\text { transduction, protein } \\
\text { localization }\end{array}$ \\
\hline 19751 & $\begin{array}{l}\text { AGGTCTTCCCTGGCACTGATA } \\
\text { TGCCAAGCATCCACA }\end{array}$ & Octopus bimaculoides & $\begin{array}{l}\text { glutamate receptor 2- } \\
\text { like }\end{array}$ & 31.9 & 1.4 & $88 \%$ & GRIA2 & $\begin{array}{l}\text { glutamate receptor activity, } \\
\text { learning, memory, and behavior }\end{array}$ \\
\hline 31348 & $\begin{array}{l}\text { TGGGAATGTAAAGCAAGATA } \\
\text { CTGCTTTTTGTGCGCT }\end{array}$ & Biomphalaria glabrata & uncharacterized & 30.1 & 4.8 & $86 \%$ & & \\
\hline 27006 & $\begin{array}{l}\text { GGTGGGGTCGCTGCAATTCTT } \\
\text { TGCGGATCAGGTCTG }\end{array}$ & Crassostrea gigas & uncharacterized & 31.9 & 1.4 & $88 \%$ & & \\
\hline 11426 & $\begin{array}{l}\text { CGTTTAGTTTTAGCAGGAGC } \\
\text { ATGCTTGTCAAAGATA }\end{array}$ & Haliotis discus hannai & microsatellite & 33.7 & 0.39 & $86 \%$ & & \\
\hline 17278 & $\begin{array}{l}\text { AGGTCATCTTGTGCATAGAC } \\
\text { CTGCCAGTGCCTTACT }\end{array}$ & Rapana venosa & microsatellite & 31.9 & 1.4 & $94 \%$ & & \\
\hline 33978 & $\begin{array}{l}\text { AGTTTGAATGGGGCAGTCAC } \\
\text { GTGCTAAGGTGGTGTC }\end{array}$ & Octopus bimaculoides & uncharacterized & 30.1 & 4.8 & $91 \%$ & & \\
\hline 63145 & $\begin{array}{l}\text { CAAGTTCCAATAGCATTTCAC } \\
\text { TGCTTGATGATGCCC }\end{array}$ & Octopus bimaculoides & uncharacterized & 33.7 & 0.39 & $91 \%$ & & \\
\hline 35977 & $\begin{array}{l}\text { TGTGGATGCTTGGCAACTCG } \\
\text { GTGCGACAGAGAATCT }\end{array}$ & Aplysia californica & uncharacterized & 33.7 & 0.39 & $94 \%$ & & \\
\hline 15186 & $\begin{array}{l}\text { CACCCTCTCTATGCAATGACA } \\
\text { TGCAAGCCCCСCTCT }\end{array}$ & Aplysia californica & uncharacterized & 30.1 & 4.8 & $86 \%$ & & \\
\hline
\end{tabular}




\section{DISCUSSION}

423 Our results reveal a complex mixture of population genetic patterns in Coralliophila violacea

424 that appear to be shaped by both geography and environment. Genome-wide data from $>3,000$

425 SNPs identified four genetic partitions concordant with traditionally recognized biogeographic

426 regions (Indian Ocean, South China Sea, Coral Triangle, and Hawai'i; (Spalding et al., 2007).

427 These findings align with a previous mitochondrial DNA study (Simmonds et al., 2018) and

428 other marine phylogeographic studies from this region (Barber et al., 2011; Carpenter et al.,

429 2010; Crandall et al., 2019). Furthermore, repeated patterns across multiple taxa suggest a

430 common origin (Avise 2000), the most likely broad-scale physical isolation of populations-

431 allopatry.

432 However, an examination of outlier loci and the correlation between allelic variation and

433 environmental variables also highlights the importance of natural selection in shaping population

434 genetic patterns. More than $2 \%$ of loci were outliers, similar to Gaither et al. (2015), showing

435 that divergence is greater than expected under neutrality (Foll \& Gaggiotti, 2008). Similarly,

436 nearly $3 \%$ of loci had strong correlations with environmental variables. Both Hawai‘ $i$ and

437 Vietnam, peripheral populations with similar climate profiles, were differentiated at neutral and

438 outlier loci. In contrast, populations more centrally located in the range of C. violacea were only

439 differentiated at neutral loci but not outliers. These results suggest that environmental

440 differences, particularly sea surface temperature, may reinforce the neutral geographic structure,

441 leading to peripheral populations' differentiation. Combined with the ecological differentiation of

442 C. violacea on different coral hosts (Simmonds et al., 2020), these results indicate that

443 diversification in marine environments is more complex and varied than currently understood

444 and includes both neutral and selective processes. 
Potential role of natural selection in shaping genetic patterns

447 While neutral loci showed a clear signal of physical limits to gene flow (below), there were also

448 significant associations between frequencies of multiple loci (3\% of total) and environmental

449 variables. The strongest genetic associations linked these loci to the SST range and SST mean.

450 Elevated SST can affect gastropods' growth and survival rates, including marine snails (Sanford

451 \& Kelly, 2011), so the link between environmentally-associated loci and temperature is not

452 unexpected. However, results also showed an interesting genetic association pattern driven by

453 the temperature at the coldest sites in the peripheral populations Hawai' $i$ and Vietnam. Thus,

454 temperature differences between the Coral Triangle and peripheral populations could enable

455 selection to drive population divergence. For example, Reid et al. (2006) found that

456 environmental and ecological factors (i.e., continental vs. oceanic habitat and primary

457 productivity) shaped intertidal snails' genetics in the Indo-Pacific. Given that peripheral

458 populations like Hawai'i have environmental conditions considered marginal for Porites' growth

459 and survival (Polato et al., 2010), such selection could act directly on $C$. violacea or indirectly by

460 selection pressure on their coral hosts. Interestingly, while all four regions sampled show unique

461 environmental signatures when examining the loci under the environmental influence,

462 STRUCTURE only differentiates between two clusters: Vietnam and Hawai' $i$ to the exclusion of

463 all others.

464 If environmental variation drives natural selection, it is reasonable to expect some

465 overlap between loci with significant associations with environmental variables and the outlier

466 loci that are putatively under selection. However, there was no overlap between these two

467 groups. This seemingly incongruous result may be a function of only examining five 
environmental variables or potentially due to uneven sample sizes. We focused on temperature and salinity because of previous studies demonstrating their selection pressure on marine

470 populations (e.g., Berg et al., 2015; DeFaveri et al., 2013; Limborg et al., 2012; Teske et al.,

471 2019). However, other variables can have an impact. For example, Gaither et al. (2015) found

472 that high turbidity and low light conditions explained divergent selection at a visual pigment

473 gene locus in a coral reef fish.

As expected for a non-model organism, few candidate loci aligned to sequences in the

NCBI database, highlighting the lack of current genomic resources for gastropods. However, two groups of genes are of interest for future research. First, conotoxin genes showed up as both

477 outlier and environmentally-associated loci. While neurotoxins have not been studied in

478 Coralliophila, venoms have been identified in other Neogastropoda (Fänge, 1984) and could be

479 important to deactivate nematocysts to facilitate feeding and living on corals. Second, another 480 gene of interest, $C H S 5$, is predicted to be involved in chitin biosynthesis, a substance found in 481 mollusc shells and radulae. Chitin is also used in the epidermis and stomach lining of 482 nudibranchs that feed on Cnidarians as protection from nematocysts (Martin et al., 2007), and 483 Coralliophila could similarly deploy chitin.

485 Populations at the periphery

486 Hawaiian populations of $C$. violacea were the most geographically isolated, $7000 \mathrm{~km}$ removed

487 from the Coral Triangle, and showed the strongest genetic differentiation. Studies reporting 488 genetic differentiation of Hawaiian populations in Indo-Pacific taxa are common and frequently 489 invoke geographic isolation (Ahti et al., 2016; J. DiBattista et al., 2012; Fernandez-Silva et al., 490 2015; Leray et al., 2010; Waldrop et al., 2016), and population bottlenecks (Szab’o et al., 2014) 
491 as primary drivers. Not only are Hawaiian populations of $C$. violacea differentiated, so too is

492 their host, Porites lobata (Baums et al., 2012; Polato et al., 2010), suggesting a common

493 diversification process. Whether by pure allopatry or isolation by distance, there are physical

494 limits to gene flow in C. violacea across this vast span of the ocean. In contrast, Vietnam

495 populations are much less geographically isolated from the core of the geographic range of $C$.

496 violacea. Our sampling location was only 10 s to 100 s of $\mathrm{km}$ from other reef systems in the South

497 China Sea with high connectivity to the Coral Triangle (Treml et al., 2012). Such extreme

498 geographic isolation cannot explain the differentiation of Vietnam.

Allopatric processes may contribute to the strong differentiation of C. violacea

500 populations from Vietnam. The South China Sea was partially enclosed during Plio-Pleistocene

501 low sea levels (Ludt \& Rocha, 2015; Voris, 2000), resulting in isolation and genetic

502 differentiation of marine taxa (Barber et al., 2000). Ocean circulation patterns also limit water

503 movement from the Coral Triangle into the South China Sea (Kool et al., 2011), creating a

504 barrier dividing populations north and south across the middle of the South China Sea (Treml et

505 al., 2015). Ocean circulation patterns have been invoked to explain C. violacea populations'

506 genetic structure from Taiwan and Taiping, a small island in the South China Sea (Lin \& Liu,

507 2008). These allopatric processes may fully explain differentiation at neutral loci. However, they

508 can't explain the grouping of Hawai'i and Vietnam populations when examining loci exhibiting

509 signals of selection. The similarity of these populations at non-neutral loci, combined with their

510 environmental similarities, strongly argues that environmental variation drives or reinforces

511 differentiation of these peripheral populations.

512 Interestingly, while peripheral populations in the Indian Ocean (Vavvaru and Pulau Weh)

513 showed a distinct Indian Ocean signature, these populations also had a substantial admixture 
514 generating from the Coral Triangle and the South China Sea. This is not surprising given the

515 volume of sea surface transport from the Pacific into the Indian Ocean through this region

516 (Gordon et al., 2012), a pattern that is observed in a wide variety of taxa (e.g., Drew \& Barber,

517 2009; Williams \& Benzie, 1998). However, this region's environmental conditions are also

518 different from other areas of the sampled range, suggesting that selection might act as it does in

519 other parts of the range of $C$. violacea. Thus, gene flow from the Coral Triangle and the South

520 China Sea or other un-sampled areas may limit the signal of environmental selection in the

521 Maldives, despite the relative isolation of these reef ecosystems.

\section{Populations at the center}

524 In contrast to peripheral populations, populations within the Coral Triangle at the core of $C$.

525 violacea's geographic range showed no evidence of divergence. Populations in the Philippines

526 (Dumaguete), eastern (Manokwari), and central Indonesia (Bunaken, Lembeh, Pulau Mengyatan,

527 Nusa Penida) all had high connectivity, echoing findings for other molluscs in the region (S. H.

528 Cheng et al., 2014; DeBoer et al., 2014; Kirkendale \& Meyer, 2004; Nuryanto \& Kochzius,

529 2009) and as predicted by coupled biophysical models of larval dispersal (Kool et al., 2011;

530 Treml et al., 2015). The only isolation observed by Coral Triangle populations was from

531 populations on the periphery in the South China Sea, the Indian Ocean, and the Central Pacific.

533 Specifically, studies of multiple taxa including giant clams (DeBoer et al., 2008, 2014; Kochzius

534 \& Nuryanto, 2008); mantis shrimp (Barber et al., 2006, 2011); echinoderms (Crandall et al.,

535 2008b); and fish (Timm \& Kochzius, 2008; Ackiss et al., 2013; Jackson et al., 2014) all show

536 strong isolation of populations spanning the Maluku Sea. This pattern has typically been 
537 attributed to the effects of the Halmahera Eddy (Barber et al., 2006) and is predicted by coupled

538 biophysical models (Kool et al., 2011; Treml et al., 2015). However, Treml et al. (2015) found

539 that the Halmahera Eddy filtered only $8.3-10.6 \%$ of simulated taxa. The strength of this filter

540 was determined by life-history traits such as reproductive output, the timing of spawning, and

541 length of larval dispersal phase. For example, C. violacea has high fecundity (Lin \& Liu, 1995),

542 spawn larvae most of the year (Soong \& Chen, 1991), and likely have a long larval duration

543 (Taylor, 1975). These traits should facilitate crossing seasonally variable dispersal barriers. In

544 contrast, giant clams (Tridacna) have relatively short-lived planktonic larvae (9-10 days;

545 Crawford et al., 1986), constraining their dispersal potential, making them more inclined to

546 diverge across filters to gene flow. As such, life history difference likely explains why

547 connectivity in the Coral Triangle isn't limited in C. violacea, as it is in other molluscs.

548 While allopatric divergence is an important process shaping marine taxa's evolutionary

549 history, physical limits to dispersal and gene flow do not operate in isolation. Our results show

550 that local adaptation to different environments may reinforce neutral divergence, especially in

551 peripheral populations. These results add to the growing recognition that various factors impact

552 diversification in coral reef species (Bowen et al., 2013; Fernandez-Silva et al., 2015; Floeter et

553 al., 2007; Hoeksema, 2007; Ludt \& Rocha, 2015; Rocha \& Bowen, 2008). Advances in high

554 throughput genome-wide sequencing will facilitate the exploration of neutral and adaptive

555 variation in concert. Combined with the improved availability of marine environmental

556 databases, we are at the leading edge of developing a more expansive view of processes driving

557 genetic divergence among populations, leading to clearer approaches to understanding evolution

558 in marine habitats. 


\section{ACKNOWLEDGMENTS}

561 This work was supported by three National Science Foundation programs (OISE-0730256,

562 OISE-1243541, and OCE-0349177) and a US Agency for International Development Grant

563 (497-A-00-10-00008-00). The Lemelson Foundation Fellowship, Conchologists of America,

564 Sigma Xi, and the UCLA Department of Ecology and Evolutionary Biology provided additional

565 funding to S. Simmonds. Finally, we acknowledge support from the Indonesian government,

566 including the Indonesian Ministry of Research and Technology (RISTEK), the Indonesian

567 Institute of Sciences (LIPI), the Nature Conservation Agency (BKSDA), and the National

568 Marine Park offices of Bunaken and Wakatobi. Sampling was covered under research permits

569 obtained in Indonesia (RISTEK 2011, 198/SIP/FRP/SMN1/2012, 187/SIP/FRP/SM/VI/2013),

570 Timor-Leste (Direccao Nacional de Pescase Aquicultura 0042/DNPA/IOP/VII/11), Vietnam, the

571 Philippines (Department of Agriculture-Bureau of Fisheries and Aquatic Resources), the

572 Maldives (Ministry of Fisheries and Aquaculture Permit No. (OTHR)30-D/INDIV/2013/116)

573 and Hawai' $i$ (Department of Land and Natural Resources SAP 2013-11). We also thank the

574 Indonesian Biodiversity Research Center at Udayana University, Institute for Environmental and

575 Marine Sciences at Silliman University, and Nha Trang University for institutional support.

576 Thank you to B. Stockwell, M. Weber, H. Nuetzel, and D. Willette for collecting specimens.

578 Conflict of Interest Statement

579 On behalf of all authors, the corresponding author states that there is no conflict of interest.

\section{REFERENCES}

582 Ackiss, A. S., Bird, C. E., Akita, Y., Santos, M. D., Tachihara, K., \& Carpenter, K. E. (2018). Genetic 583 patterns in peripheral marine populations of the fusilier fish Caesio cuning within the Kuroshio 
Current. Ecology and Evolution, 8(23), 11875-11886. https://doi.org/10.1002/ece3.4644

Ackiss, A. S., Pardede, S., Crandall, E. D., Ablan-Lagman, M. C. A., Ambariyanto, Romena, N., Barber, P. H., \& Carpenter, K. E. (2013). Pronounced genetic structure in a highly mobile coral reef fish, Caesio cuning, in the Coral Triangle. Marine Ecology Progress Series, 480, 185-197. https://doi.org/10.3354/meps10199

Ahti, P. A., Coleman, R. R., DiBattista, J. D., Berumen, M. L., Rocha, L. A., \& Bowen, B. W. (2016). Phylogeography of Indo-Pacific reef fishes: sister wrasses Coris gaimard and C. cuvieri in the Red Sea, Indian Ocean and Pacific Ocean. Journal of Biogeography, 43(6), 1103-1115. https://onlinelibrary.wiley.com/doi/abs/10.1111/jbi.12712

Barber, P.H., \& Meyer, C.P. (2014) Pluralism explains diversity in the Coral Triangle. In: Mora C (ed) Ecology of Fishes on Coral Reefs: pp. 258-263; Cambridge University Press.

Barber, P. H., Cheng, S. H., Erdmann, M. V., \& Tengardjaja, K. (2011). Evolution and conservation of marine biodiversity in the Coral Triangle: insights from stomatopod Crustacea. Crustacean Issues, 19, 129-156. https://content.taylorfrancis.com/books/e/download?dac=C2010-0-276537\&isbn=9781439840740\&doi=10.1201/b11113-10\&format $=$ pdf

Barber, P. H., Erdmann, M. V., \& Palumbi, S. R. (2006). Comparative phylogeography of three codistributed stomatopods: origins and timing of regional lineage diversification in the Coral Triangle. Evolution, 60(9), 1825-1839. https://www.ncbi.nlm.nih.gov/pubmed/17089967

Barber, P. H., Palumbi, S. R., Erdmann, M. V., \& Moosa, M. K. (2000). Biogeography. A marine Wallace's line? Nature, 406(6797), 692-693. https://doi.org/10.1038/35021135

Baums, I. B., Boulay, J. N., Polato, N. R., \& Hellberg, M. E. (2012). No gene flow across the Eastern Pacific Barrier in the reef-building coral Porites lobata. Molecular Ecology, 21(22), 5418-5433. https://doi.org/10.1111/j.1365-294X.2012.05733.x

Berg, P. R., Jentoft, S., Star, B., Ring, K. H., Knutsen, H., Lien, S., Jakobsen, K. S., \& André, C. (2015). Adaptation to low salinity promotes genomic divergence in Atlantic Cod (Gadus morhua L.). Genome Biology and Evolution, 7(6), 1644-1663. https://doi.org/10.1093/gbe/evv093

Bowen, B. W., Rocha, L. A., Toonen, R. J., Karl, S. A., \& ToBo Laboratory. (2013). The origins of tropical marine biodiversity. Trends in Ecology \& Evolution, 28(6), 359-366. https://doi.org/10.1016/j.tree.2013.01.018

Bowen, B. W., Shanker, K., Yasuda, N., Celia, M., Malay, M. C. (machel) D., von der Heyden, S., Paulay, G., Rocha, L. A., Selkoe, K. A., Barber, P. H., Williams, S. T., Lessios, H. A., Crandall, E. D., Bernardi, G., Meyer, C. P., Carpenter, K. E., \& Toonen, R. J. (2014). Phylogeography unplugged: comparative surveys in the genomic era. Bulletin of Marine Science, 90(1), 13-46. https://doi.org/10.5343/bms.2013.1007

Briggs, J. C. (1992). The marine East Indies: Centre of origin? Global Ecology and Biogeography Letters, 2(5), 149. https://doi.org/10.2307/2997803

Briggs, J. C. (2006). Proximate sources of marine biodiversity. Journal of Biogeography, 33(1), 1-10. https://doi.org/10.1111/j.1365-2699.2005.01374.x

Burgess, S. C., Treml, E. A., \& Marshall, D. J. (2012). How do dispersal costs and habitat selection influence realized population connectivity? Ecology, 93(6), 1378-1387.

https://www.ncbi.nlm.nih.gov/pubmed/22834378

Carpenter, K. E., Barber, P. H., Crandall, E. D., Ablan-Lagman, M. C. A., Ambariyanto, Mahardika, G. N., Manjaji-Matsumoto, B. M., Juinio-Meñez, M. A., Santos, M. D., Starger, C. J., \& Toha, A. H. A. (2010). Comparative phylogeography of the Coral Triangle and Implications for Marine Management. Journal of Marine Biology, 2011. https://doi.org/10.1155/2011/396982

Cheng, S. H. (2015). Evolution and Population Genomics of Loliginid Squids [UCLA]. https://escholarship.org/uc/item/0zw3h4ps

Cheng, S. H., Anderson, F. E., Bergman, A., Mahardika, G. N., Muchlisin, Z. A., Dang, B. T., Calumpong, H. P., Mohamed, K. S., Sasikumar, G., Venkatesan, V., \& Barber, P. H. (2014). Molecular evidence for co-occurring cryptic lineages within the Sepioteuthis cf. lessoniana species 
complex in the Indian and Indo-West Pacific Oceans. Hydrobiologia, 725(1), 165-188. https://doi.org/10.1007/s10750-013-1778-0

Coop, G., Witonsky, D., Di Rienzo, A., \& Pritchard, J. K. (2010). Using environmental correlations to identify loci underlying local adaptation. Genetics, 185(4), 1411-1423. https://doi.org/10.1534/genetics.110.114819

Craig, M. T., Eble, J. A., Bowen, B. W., \& Robertson, D. R. (2007). High genetic connectivity across the Indian and Pacific Oceans in the reef fish Myripristis berndti (Holocentridae). Marine Ecology Progress Series, 334, 245-254. https://doi.org/10.3354/meps334245

Crandall, E. D., Frey, M. A., Grosberg, R. K., \& Barber, P. H. (2008a). Contrasting demographic history and phylogeographical patterns in two Indo-Pacific gastropods. Molecular Ecology, 17(2), 611-626. https://doi.org/10.1111/j.1365-294X.2007.03600.x

Crandall, E. D., Jones, M. E., Muñoz, M. M., Akinronbi, B., Erdmann, M. V., \& Barber, P. H. (2008b). Comparative phylogeography of two seastars and their ectosymbionts within the Coral Triangle. Molecular Ecology, 17(24), 5276-5290. https://doi.org/10.1111/j.1365-294X.2008.03995.x

Crandall, E. D., Sbrocco, E. J., DeBoer, T. S., Barber, P. H., \& Carpenter, K. E. (2012) Expansion dating: Calibrating molecular clocks in marine species from expansions onto the Sunda Shelf following the last glacial maximum, Molecular Biology and Evolution, 29(2) 707719, https://doi.org/10.1093/molbev/msr227

Crandall, E. D., Riginos, C., Bird, C., Liggins, L., Treml, E., Beger, M., Barber, P. H., Connolly, S. R., Cowman, P. F., DiBattista, J. D., Eble, J. A., Magnuson, S. F., Horne, J. B., Kochzius, M., Lessios, H. A., Yin Vanson Liu, S., Ludt, W. B., Madduppa, H., Pandolfi, J. M., ... Gaither, M. R. (2019). The molecular biogeography of the Indo-Pacific: testing hypotheses with multispecies genetic patterns. Global Ecology and Biogeography: A Journal of Macroecology. https://onlinelibrary.wiley.com/doi/abs/10.1111/geb.12905

Crawford, C. M., Nash, W. J., \& Lucas, J. S. (1986). Spawning induction, and larval and juvenile rearing of the giant clam, Tridacna gigas. Aquaculture, 58(3-4), 281-295. https://doi.org/10.1016/00448486(86)90094-3

DeBoer, T. S., Naguit, M. R. A., Erdmann, M. V., Ablan-Lagman, M. C. A., Ambariyanto, Carpenter, K. E., Toha, A. H. A., \& Barber, P. H. (2014). Concordance between phylogeographic and biogeographic boundaries in the Coral Triangle: Conservation implications based on comparative analyses of multiple giant clam species. Bulletin of Marine Science, 90(1), 277-300. https://doi.org/10.5343/bms.2013.1003

DeBoer, T. S., Subia, M. D., Ambariyanto, Erdmann, M. V., Kovitvongsa, K., \& Barber, P. H. (2008). Phylogeography and limited genetic connectivity in the endangered boring giant clam across the Coral Triangle. Conservation Biology, 22(5), 1255-1266. https://doi.org/10.1111/j.15231739.2008.00983.x

DeFaveri, J., Jonsson, P. R., \& Merilä, J. (2013). Heterogeneous genomic differentiation in marine threespine sticklebacks: adaptation along an environmental gradient. Evolution, 67(9), 2530-2546. https://doi.org/10.1111/evo.12097

DiBattista, J. D., Roberts, M. B., Bouwmeester, J., Bowen, B. W., Coker, D. J., Lozano-Cortés, D. F., Howard Choat, J., Gaither, M. R., Hobbs, J.-P. A., Khalil, M. T., \& Others. (2016). A review of contemporary patterns of endemism for shallow water reef fauna in the Red Sea. Journal of Biogeography, 43(3), 423-439. https://onlinelibrary.wiley.com/doi/abs/10.1111/jbi.12649

DiBattista, J., Waldrop, E., Bowen, B. W., Schultz, J. K., Gaither, M. R., Pyle, R. L., \& Rocha, L. A. (2012). Twisted sister species of pygmy angelfishes: discordance between taxonomy, coloration, and phylogenetics. Coral Reefs, 31(3), 839-851. https://doi.org/10.1007/s00338-012-0907-y

Dohna, T. A., Timm, J., Hamid, L., \& Kochzius, M. (2015). Limited connectivity and a phylogeographic break characterize populations of the pink anemonefish, Amphiprion perideraion, in the Indo-Malay Archipelago: inferences from a mitochondrial and microsatellite loci. Ecology and Evolution, 5(8), 1717-1733. https://doi.org/10.1002/ece3.1455 
684

Drew, J., \& Barber, P. H. (2009). Sequential cladogenesis of the reef fish Pomacentrus moluccensis (Pomacentridae) supports the peripheral origin of marine biodiversity in the Indo-Australian archipelago. Molecular Phylogenetics and Evolution, 53(1), 335-339. https://doi.org/10.1016/j.ympev.2009.04.014

Evanno, G., Regnaut, S., \& Goudet, J. (2005). Detecting the number of clusters of individuals using the software STRUCTURE: a simulation study. Molecular Ecology, 14(8), 2611-2620. https://doi.org/10.1111/j.1365-294X.2005.02553.x

Excoffier, L., \& Lischer, H. E. L. (2010). Arlequin suite ver 3.5: a new series of programs to perform population genetics analyses under Linux and Windows. Molecular Ecology Resources, 10(3), 564567. https://doi.org/10.1111/j.1755-0998.2010.02847.x

Fänge, R. (1984). Venoms and venom glands of marine molluscs. In Bolis L., Zadunaisky J., Gilles R. (Ed.), Toxins, Drugs, and Pollutants in Marine Animals (pp. 47-62). Springer Berlin Heidelberg. https://doi.org/10.1007/978-3-642-69903-0 5

Fernandez-Silva, I., Randall, J. E., Coleman, R. R., DiBattista, J. D., Rocha, L. A., Reimer, J. D., Meyer, C. G., \& Bowen, B. W. (2015). Yellow tails in the Red Sea: phylogeography of the Indo-Pacific goatfish Mulloidichthys flavolineatus reveals isolation in peripheral provinces and cryptic evolutionary lineages. Journal of Biogeography, 42(12), 2402-2413. https://onlinelibrary.wiley.com/doi/abs/10.1111/jbi.12598

Floeter, S. R., Rocha, L. A., Robertson, D. R., Joyeux, J. C., Smith-Vaniz, W. F., Wirtz, P., Edwards, A. J., Barreiros, J. P., Ferreira, C. E. L., Gasparini, J. L., Brito, A., Falcón, J. M., Bowen, B. W., \& Bernardi, G. (2007). Atlantic reef fish biogeography and evolution. Journal of Biogeography, 35(1), 22-47. https://doi.org/10.1111/j.1365-2699.2007.01790.x

Foll, M., \& Gaggiotti, O. (2008). A genome-scan method to identify selected loci appropriate for both dominant and codominant markers: a Bayesian perspective. Genetics, 180(2), 977-993. https://doi.org/10.1534/genetics.108.092221

Forsman, Z. H., Barshis, D. J., Hunter, C. L., \& Toonen, R. J. (2009). Shape-shifting corals: molecular markers show morphology is evolutionarily plastic in Porites. BMC Evolutionary Biology, 9, 45. https://doi.org/10.1186/1471-2148-9-45

Forsman, Z., Wellington, G. M., Fox, G. E., \& Toonen, R. J. (2015). Clues to unraveling the coral species problem: distinguishing species from geographic variation in Porites across the Pacific with molecular markers and microskeletal traits. PeerJ, 3, e751. https://doi.org/10.7717/peerj.751

Gaither, M. R., Bernal, M. A., Coleman, R. R., Bowen, B. W., Jones, S. A., Simison, W. B., \& Rocha, L. A. (2015). Genomic signatures of geographic isolation and natural selection in coral reef fishes. Molecular Ecology, 24(7), 1543-1557. https://doi.org/10.1111/mec.13129

Gaither, M. R., Bowen, B. W., Bordenave, T.-R., Rocha, L. A., Newman, S. J., Gomez, J. A., van Herwerden, L., \& Craig, M. T. (2011). Phylogeography of the reef fish Cephalopholis argus (Epinephelidae) indicates Pleistocene isolation across the Indo-Pacific barrier with contemporary overlap in the Coral Triangle. BMC Evolutionary Biology, 11(1), 189. https://doi.org/10.1186/14712148-11-189

Gaither, M. R., Toonen, R. J., Robertson, D. R., Planes, S., \& Bowen, B. W. (2010). Genetic evaluation of marine biogeographical barriers: perspectives from two widespread Indo-Pacific snappers (Lutjanus kasmira and Lutjanus fulvus). Journal of Biogeography, 37(1), 133-147. https://onlinelibrary.wiley.com/doi/abs/10.1111/j.1365-2699.2009.02188.x

Gavrilets, S. (2003). Perspective: models of speciation: what have we learned in 40 years? Evolution; International Journal of Organic Evolution, 57(10), 2197-2215. https://onlinelibrary.wiley.com/doi/abs/10.1111/j.0014-3820.2003.tb00233.x

Gordon, A. L., Huber, B. A., \& Metzger, E. J. (2012). South China Sea throughflow impact on the Indonesian throughflow. Geophysical Research Letters, 39(11).

Günther, T., \& Coop, G. (2013). Robust identification of local adaptation from allele frequencies. Genetics, 195(1), 205-220. https://doi.org/10.1534/genetics.113.152462 
Hoegh-Guldberg, O. (1999). Climate change, coral bleaching and the future of the world's coral reefs. Marine and Freshwater Research, 50, 839-866.

Hoeksema, B. W. (2007). Delineation of the Indo-Malayan centre of maximum marine biodiversity: The Coral Triangle. In W. Renema (Ed.), Biogeography, Time, and Place: Distributions, Barriers, and Islands (pp. 117-178). Springer Netherlands. https://doi.org/10.1007/978-1-4020-6374-9 5

Horne, J. B. (2014). Thinking outside the barrier: neutral and adaptive divergence in Indo-Pacific coral reef faunas. Evolutionary Ecology, 28(6), 991-1002. https://doi.org/10.1007/s10682-014-9724-9

Jeffreys, H. (1998). The Theory of Probability. OUP Oxford. https://market.android.com/details?id=bookvh9Act9rtzQC

Johannesson, K., \& André, C. (2006). Life on the margin: genetic isolation and diversity loss in a peripheral marine ecosystem, the Baltic Sea. Molecular Ecology, 15(8), 2013-2029. https://doi.org/10.1111/j.1365-294X.2006.02919.x

Kawecki, T. J. (2008). Adaptation to marginal habitats. Annual Review of Ecology, Evolution, and Systematics, 39(1), 321-342. https://doi.org/10.1146/annurev.ecolsys.38.091206.095622

Kelly, R. P., \& Palumbi, S. R. (2010). Genetic structure among 50 species of the northeastern Pacific rocky intertidal community. PloS One, 5(1), e8594. https://doi.org/10.1371/journal.pone.0008594

Kirkendale, L. A., \& Meyer, C. P. (2004). Phylogeography of the Patelloida profunda group (Gastropoda: Lottidae): diversification in a dispersal-driven marine system. Molecular Ecology, 13(9), 2749-2762. https://doi.org/10.1111/j.1365-294X.2004.02284.X

Kochzius, M., Seidel, C., Hauschild, J., Kirchhoff, S., Mester, P., Meyer-Wachsmuth, I., Nuryanto, A., \& Timm, J. (2009). Genetic population structures of the blue starfish Linckia laevigata and its gastropod ectoparasite Thyca crystallina. Marine Ecology Progress Series, 396, 211-219. https://doi.org/10.3354/meps08281

Kool, J. T., Paris, C. B., Barber, P. H., \& Cowen, R. K. (2011). Connectivity and the development of population genetic structure in Indo-West Pacific coral reef communities. Global Ecology and Biogeography: A Journal of Macroecology, 20(5), 695-706. https://onlinelibrary.wiley.com/doi/abs/10.1111/j.1466-8238.2010.00637.x

Kopelman, N. M., Mayzel, J., Jakobsson, M., Rosenberg, N. A., \& Mayrose, I. (2015). Clumpak: a program for identifying clustering modes and packaging population structure inferences across $\mathrm{K}$. Molecular Ecology Resources, 15(5), 1179-1191. https://doi.org/10.1111/1755-0998.12387

Kuhnt, W., Holbourn, A., Hall, R., Zuvela, M., \& Käse, R. (2004). Neogene history of the Indonesian throughflow. Continent-Ocean Interactions within East Asian Marginal Seas. Geophysical Monograph, 149, 299-320. http://searg.rhul.ac.uk/pubs/kuhnt_etal_2004\%20Neogene\%20Indonesian\%20throughflow.pdf

Leray, M., Beldade, R., Holbrook, S. J., Schmitt, R. J., Planes, S., \& Bernardi, G. (2010). Allopatric divergence and speciation in coral reef fish: the three-spot dascyllus, Dascyllus trimaculatus, species complex. Evolution, 64(5), 1218-1230. https://doi.org/10.1111/j.1558-5646.2009.00917.x

Limborg, M. T., Helyar, S. J., De Bruyn, M., Taylor, M. I., Nielsen, E. E., Ogden, R., Carvalho, G. R., FPT Consortium, \& Bekkevold, D. (2012). Environmental selection on transcriptome-derived SNPs in a high gene flow marine fish, the Atlantic herring (Clupea harengus). Molecular Ecology, 21(15), 3686-3703. https://doi.org/10.1111/j.1365-294X.2012.05639.x

Lin, T.-Y., \& Liu, L.-L. (2008). Low levels of genetic differentiation among populations of the coralinhabiting snail Coralliophila violacea (Gastropoda: Coralliophilidae) in regions of the Kuroshio and South China Sea. Zoological Studies, 47(1), 17. $\mathrm{http}: / /$ citeseerx.ist.psu.edu/viewdoc/download?doi=10.1.1.654.4420\&rep=rep1\&type=pdf

Lin, T.-Y., \& Liu, P.-J. (1995). Fecundity of female coral-inhabiting snails, Coralliophila violacea (Gastropoda: Coralliophilidae). The Veliger, 38(4), 319-322.

Lischer, H. E. L., \& Excoffier, L. (2012). PGDSpider: an automated data conversion tool for connecting population genetics and genomics programs. Bioinformatics, 28(2), 298-299.

783 https://doi.org/10.1093/bioinformatics/btr642 
Litton, C. D., \& Jefferys, H. (1984). Theory of Probability (3rd Edition). Oxford University Press.

Liu, S.-Y. V., Chang, F.-T., Borsa, P., Chen, W.-J., \& Dai, C.-F. (2014). Phylogeography of the humbug damselfish, Dascyllus aruanus (Linnaeus, 1758): Evidence of Indo-Pacific vicariance and genetic differentiation of peripheral populations. Biological Journal of the Linnean Society. Linnean Society of London, 113(4), 931-942. https://doi.org/10.1111/bij.12378

Liu, S. Y. V., Tuanmu, M. N., Rachmawati, R., Mahardika, G. N., \& Barber, P. H. (2019) Integrating phylogeographic and ecological niche approaches to delimitating cryptic lineages in the blue-green damselfish (Chromis viridis). PeerJ., 7:e7384. doi:10.7717/peerj.7384

Longo, G., \& Bernardi, G. (2015). The evolutionary history of the embiotocid surfperch radiation based on genome-wide RAD sequence data. Molecular Phylogenetics and Evolution, 88, 55-63. https://doi.org/10.1016/j.ympev.2015.03.027

Lourie, S. A., Green, D. M., \& Vincent, A. C. J. (2005). Dispersal, habitat differences, and comparative phylogeography of Southeast Asian seahorses (Syngnathidae: Hippocampus). Molecular Ecology, 14(4), 1073-1094. https://doi.org/10.1111/j.1365-294X.2005.02464.x

Ludt, W. B., \& Rocha, L. A. (2015). Shifting seas: the impacts of Pleistocene sea-level fluctuations on the evolution of tropical marine taxa. Journal of Biogeography, 42(1), 25-38. https://onlinelibrary.wiley.com/doi/abs/10.1111/jbi.12416

Martin, R., Hild, S., Walther, P., Ploss, K., Boland, W., \& Tomaschko, K.-H. (2007). Granular chitin in the epidermis of nudibranch molluscs. The Biological Bulletin, 213(3), 307-315. https://doi.org/10.2307/25066648

Meyer, C. P., Geller, J. B., \& Paulay, G. (2005). Fine scale endemism on coral reefs: archipelagic differentiation in turbinid gastropods. Evolution, 59(1), 113-125. https://www.ncbi.nlm.nih.gov/pubmed/15792232

Narum, S. R. (2006). Beyond Bonferroni: Less conservative analyses for conservation genetics. Conservation Genetics, 7(5), 783-787. https://doi.org/10.1007/s10592-005-9056-y

Nuryanto, A., \& Kochzius, M. (2009). Highly restricted gene flow and deep evolutionary lineages in the giant clam Tridacna maxima. Coral Reefs, 28(3), 607-619. https://doi.org/10.1007/s00338-009$0483-y$

Polato, N. R., Concepcion, G. T., Toonen, R. J., \& Baums, I. B. (2010). Isolation by distance across the Hawaiian Archipelago in the reef-building coral Porites lobata. Molecular Ecology, 19(21), 46614677. https://doi.org/10.1111/j.1365-294X.2010.04836.x

Pritchard, J. K., Stephens, M., \& Donnelly, P. (2000). Inference of population structure using multilocus genotype data. Genetics, 155(2), 945-959. https://www.ncbi.nlm.nih.gov/pubmed/10835412

Raynal, J. M., Crandall, E. D., Barber, P. H., Mahardika, G. N., Lagman, M. C., \& Carpenter, K. E. (2014). Basin isolation and oceanographic features influencing lineage divergence in the humbug damselfish (Dascyllus aruanus) in the Coral Triangle. Bulletin of Marine Science, 90(1), 513-532. https://doi.org/10.5343/bms.2013.1017

Reid, D. G., Lal, K., Mackenzie-Dodds, J., Kaligis, F., Littlewood, D. T. J., \& Williams, S. T. (2006). Comparative phylogeography and species boundaries in Echinolittorina snails in the central IndoWest Pacific. Journal of Biogeography, 33(6), 990-1006. https://doi.org/10.1111/j.13652699.2006.01469.x

Rocha, L. A., \& Bowen, B. W. (2008). Speciation in coral-reef fishes. Journal of Fish Biology, 72(5), 1101-1121. https://onlinelibrary.wiley.com/doi/abs/10.1111/j.1095-8649.2007.01770.x

Saenz-Agudelo, P., Dibattista, J. D., Piatek, M. J., Gaither, M. R., Harrison, H. B., Nanninga, G. B., \& Berumen, M. L. (2015). Seascape genetics along environmental gradients in the Arabian Peninsula: insights from ddRAD sequencing of anemonefishes. Molecular Ecology, 24(24), 6241-6255. https://doi.org/10.1111/mec.13471

Sanford, E., \& Kelly, M. W. (2011). Local adaptation in marine invertebrates. Annual Review of Marine Science, 3, 509-535. https://doi.org/10.1146/annurev-marine-120709-142756

Sbrocco, E. J., \& Barber, P. H. (2013). MARSPEC: ocean climate layers for marine spatial ecology: 
Ecological Archives E094-086. Ecology, 94(4), 979-979. https://esajournals.onlinelibrary.wiley.com/doi/abs/10.1890/12-1358.1

Shinoda, T., Han, W., Metzger, E. J., \& Hurlburt, H. E. (2012). Seasonal variation of the Indonesian Throughflow in Makassar Strait. Journal of Physical Oceanography, 42(7), 1099-1123. https://doi.org/10.1175/JPO-D-11-0120.1

Simmonds, S. E., Chou, V., Cheng, S. H., \& Rachmawati, R. (2018). Evidence of host-associated divergence from coral-eating snails (genus Coralliophila) in the Coral Triangle. Coral Reefs. 37(2), 355-371. https://link.springer.com/article/10.1007/s00338-018-1661-6

Simmonds, S. E., Fritts-Penniman, A. L., Cheng, S. H., Mahardika, G. N., \& Barber, P. H. (2020). Genomic signatures of host-associated divergence and adaptation in a coral-eating snail, Coralliophila violacea (Kiener, 1836). Ecology and Evolution, 10(4), 1817-1837. https://doi.org/10.1002/ece3.5977

Slatkin, M. (1993). Isolation by distance in equilibrium and non-equilibrium populations. Evolution, 47(1), 264-279. https://doi.org/10.1111/j.1558-5646.1993.tb01215.x

Soong, K., \& Chen, J.-L. (1991). Population structure and sex-change in the coral-inhabiting snail Coralliophila violacea at Hsiao-Liuchiu, Taiwan. Marine Biology, 111(1), 81-86. https://doi.org/10.1007/BF01986349

Spalding, M. D., Fox, H. E., Allen, G. R., Davidson, N., Ferdaña, Z. A., Finlayson, M., Halpern, B. S., Jorge, M. A., Lombana, A., Lourie, S. A., Martin, K. D., McManus, E., Molnar, J., Recchia, C. A., \& Robertson, J. (2007). Marine ecoregions of the world: A bioregionalization of coastal and shelf areas. Bioscience, 57(7), 573-583. https://doi.org/10.1641/B570707

Szab'o, Z., Snelgrove, B., Craig, M. T., Rocha, L. A., \& Bowen, B. W. (2014). Phylogeography of the manybar goatfish, Parupeneus multifasciatus, reveals isolation of the Hawaiian Archipelago and a cryptic species in the Marquesas Islands. Bulletin of Marine Science, 90(1), 493-512. https://doi.org/10.5343/bms.2013.1032

Taylor, J. B. (1975). Planktonic prosobranch veligers of Kaneohe Bay, Hawaiian Island. Ph. D. Dissertation. Univ. Hawaii.

Teske, P. R., Sandoval-Castillo, J., Golla, T. R., Emami-Khoyi, A., Tine, M., von der Heyden, S., \& Beheregaray, L. B. (2019). Thermal selection as a driver of marine ecological speciation. Proceedings of the Royal Society B: Biological Sciences, 286(1896), 20182023. https://doi.org/10.1098/rspb.2018.2023

Timm, J., \& Kochzius, M. (2008). Geological history and oceanography of the Indo-Malay Archipelago shape the genetic population structure in the false clown anemonefish (Amphiprion ocellaris). Molecular Ecology, 17(18), 3999-4014. https://onlinelibrary.wiley.com/doi/abs/10.1111/j.1365294X.2008.03881.x

Tornabene, L., Valdez, S., Erdmann, M., \& Pezold, F. (2015). Support for a "Center of Origin" in the Coral Triangle: cryptic diversity, recent speciation, and local endemism in a diverse lineage of reef fishes (Gobiidae: Eviota). Molecular Phylogenetics and Evolution, 82 Pt A, 200-210. https://doi.org/10.1016/j.ympev.2014.09.012

Treml, E. A., Roberts, J., Halpin, P. N., Possingham, H. P., \& Riginos, C. (2015). The emergent geography of biophysical dispersal barriers across the Indo-West Pacific. Diversity \& Distributions, 21(4), 465-476. https://doi.org/10.1111/ddi.12307

Treml, E. A., Roberts, J. J., Chao, Y., Halpin, P. N., Possingham, H. P., \& Riginos, C. (2012) Reproductive output and duration of the pelagic larval stage determine seascape-wide connectivity of marine populations. Integrative and Comparative Biology, 52(4) 525537, https://doi.org/10.1093/icb/ics101

Voris, H. K. (2000). Maps of Pleistocene sea levels in Southeast Asia: shorelines, river systems and time durations. Journal of Biogeography, 27(5), 1153-1167. https://doi.org/10.1046/j.13652699.2000.00489.x

Waldrop, E., Hobbs, J.-P. A., Randall, J. E., DiBattista, J. D., Rocha, L. A., Kosaki, R. K., Berumen, M. 
L., \& Bowen, B. W. (2016). Phylogeography, population structure and evolution of coral-eating butterflyfishes (Family Chaetodontidae, genus Chaetodon, subgenus Corallochaetodon). Journal of Biogeography, 43(6), 1116-1129. https://doi.org/10.1111/jbi.12680

Wang, S., Meyer, E., McKay, J. K., \& Matz, M. V. (2012). 2b-RAD: a simple and flexible method for genome-wide genotyping. Nature Methods, 9(8), 808-810. https://doi.org/10.1038/nmeth.2023

Williams, S. T., \& Benzie, J. A. H. (1998). Evidence of a biogeographic break between populations of a high dispersal starfish: Congruent regions within the Indo-West Pacific defined by color morphs, mtDNA, and allozyme data. Evolution, 52(1), 87-99. https://doi.org/10.1111/j.15585646.1998.tb05141.x

Wright, S. (1943). Isolation by distance. Genetics, 28(2), 114-138. https://www.ncbi.nlm.nih.gov/pubmed/17247074

895

\section{Author Contributions}

897 SES and PHB secured funding, conceptualized the study, worked out the methodology, and led

898 the original manuscript's writing. SES, AFP, SHC, and PHB obtained permits and collected

899 samples. SES, AFP, and SHC conducted lab work. SES performed data analyses and

900 visualization. GM provided resources and project administration. All co-authors contributed to

901 editing and revisions. 
bioRxiv preprint doi: https://doi.org/10.1101/2021.06.15.448144; this version posted June 16, 2021. The copyright holder for this preprint (which was not certified by peer review) is the author/funder. All rights reserved. No reuse allowed without permission.

902 